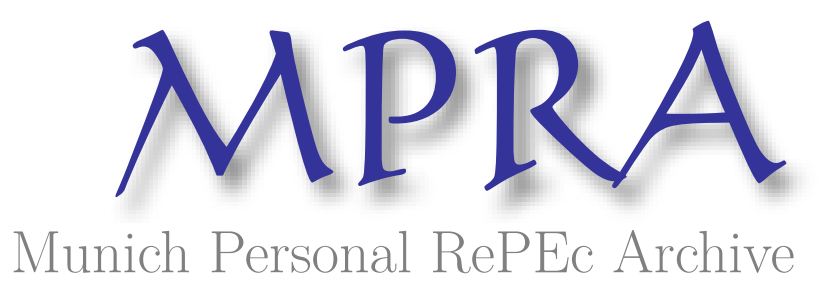

\title{
The impact of Brexit on Israel and neighbouring Arab states in times of the COVID-19 crisis
}

Kohnert, Dirk

Institute of African Afairs, GIGA-Hamburg

8 August 2021

Online at https://mpra.ub.uni-muenchen.de/109100/

MPRA Paper No. 109100, posted 23 Aug 2021 13:48 UTC 


\title{
The impact of Brexit on Israel and neighbouring Arab states in times of the COVID-19 crisis
}

\author{
Dirk Kohnert ${ }^{1}$
}

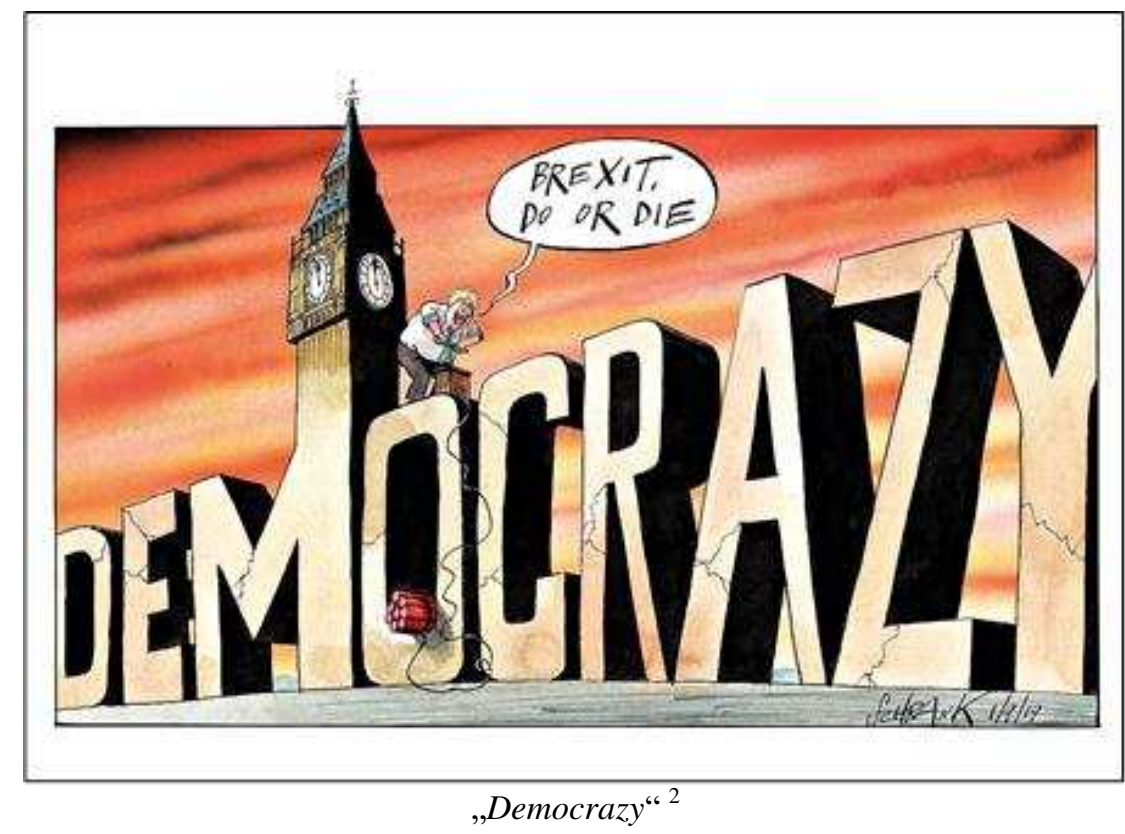

\begin{abstract}
The combined effects of Brexit and the COVID-19 pandemic on British foreign- and trade relations to Israel and its Arab neighbours constitute a particularly sensitive case. A destabilization of these countries could impact seriously stability and security, not just of the Middle-East region, but on the whole world. So far, the preliminary effects are ambivalent. Whereas Britons entertained reasoned hope for a 'Corona miracle' and a marvellous economic recovery in 2021, the prospects for Israel, the occupied Palestinian territories, Lebanon, Jordan and Egypt were less rosy. Presumably, Brexit is likely to harm the United Kingdom in the medium and long run. The post-Brexit impact on Israel and its Arab neighbours will be negative as well, but probably only be felt in the medium and long term also. However, the direct and indirect negative effects of the global COVID-19 crisis will by far outdo the Brexit impact.
\end{abstract}

Keywords: Brexit, COVID-19-pandemic, Corona, economic growth, Israel, Palestine, Lebanon, Jordan, Egypt, United Kingdom, international trade, free trade area, customs union, Anglosphere

JEL-code: F13, F15, F22, F52, F68, I14, N1, N40, O24, O5, Z13

\footnotetext{
${ }^{1}$ Dirk Kohnert, deputy director (retired) of Institute of African Affairs, GIGA, Hamburg. Draft : 8 August 2021.

${ }^{2}$ Schrankartoons.com (accessed: 6 August 2021). - Cartoonist Peter Schrank published the cartoon in the Sunday Business Post, showing Premier Boris Johnson as Westminster's 'demolition man' (Sayers, 2019). Peter Schrank is a political cartoonist, publishing among others in the The Ecomist, Basler Zeitung, The Guardian and The Times (Linkedin, Peter Schrank).
} 


\section{Introduction}

The British voted $52 \%$ to $48 \%$ in favour of leaving the European Union (EU) in a referendum on 23 June 2016. The Brexit rules in force since 31 January 2020 hurt the British economy. Since the expiration of the transition period on 31 December 2020, the United Kingdom (UK) is no longer part of the European Union Customs Union and the European Single Market. Yet, the full scale of the damage, hitting trade and deepening labour shortages, is still uncertain, because the impact is overloaded by the economic effect of the Covid-19 pandemic (Giles, 2021).

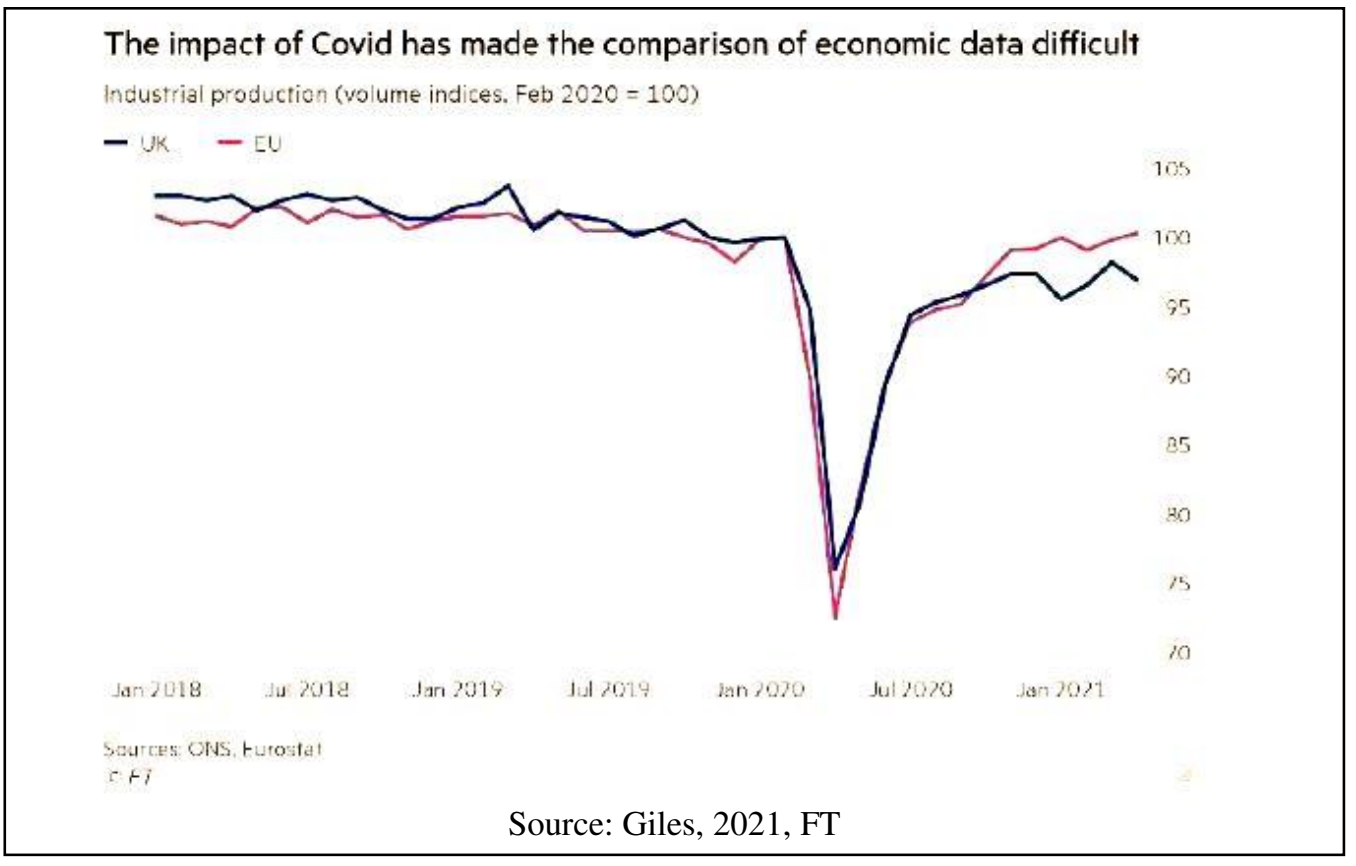

Graph 1: Brexit impact on UK industrial production, 2018 - 2021

The Brexit effects became visible first concerning the trade in goods. But the estimated impact depends largely on which statistics are used. According to the UK's Office for National Statistics (ONS), exports to the EU were $5 \%$ lower in April 2021 than last December but cut by $24 \%$ when measured by Eurostat over the same period (Giles, 2021). Likewise, the value of imports of trade in goods from the EU to the UK was $19 \%$ down over the same period, according to the ONS, while Eurostat recorded only a $13 \%$ decline.

Yet, economists generally agree about the long term Brexit effects, e.g about a reduction of British GDP by about $4 \%$ compared with remaining inside the EU. For the years to come, much depends on the degree of supply chain ruptures between Britain and the EU-27 as well as the extent to which the UK becomes less attractive to investors.

Moreover, the new restrictions concerning labour movement, introduced with Brexit, limiting the rights of EU citizens to come and work in Britain, raised concerns about labour shortages (Giles, 2021). Though, here again, it is difficult to differentiate. Labour shortages resulted from an impact mix of the Covid-crisis and Brexit. There were similar trends observed in other EU countries which suggested that it was not solely a Brexit effect. Employers had to realize in some sectors such as social care that the times when they could expect labour to be freely available were over and that on the contrary, they needed to pay more to ensure available staff (Giles, 2021). 
Graph 2: Brexit impact on UK job vacancies, 2016 - 2021

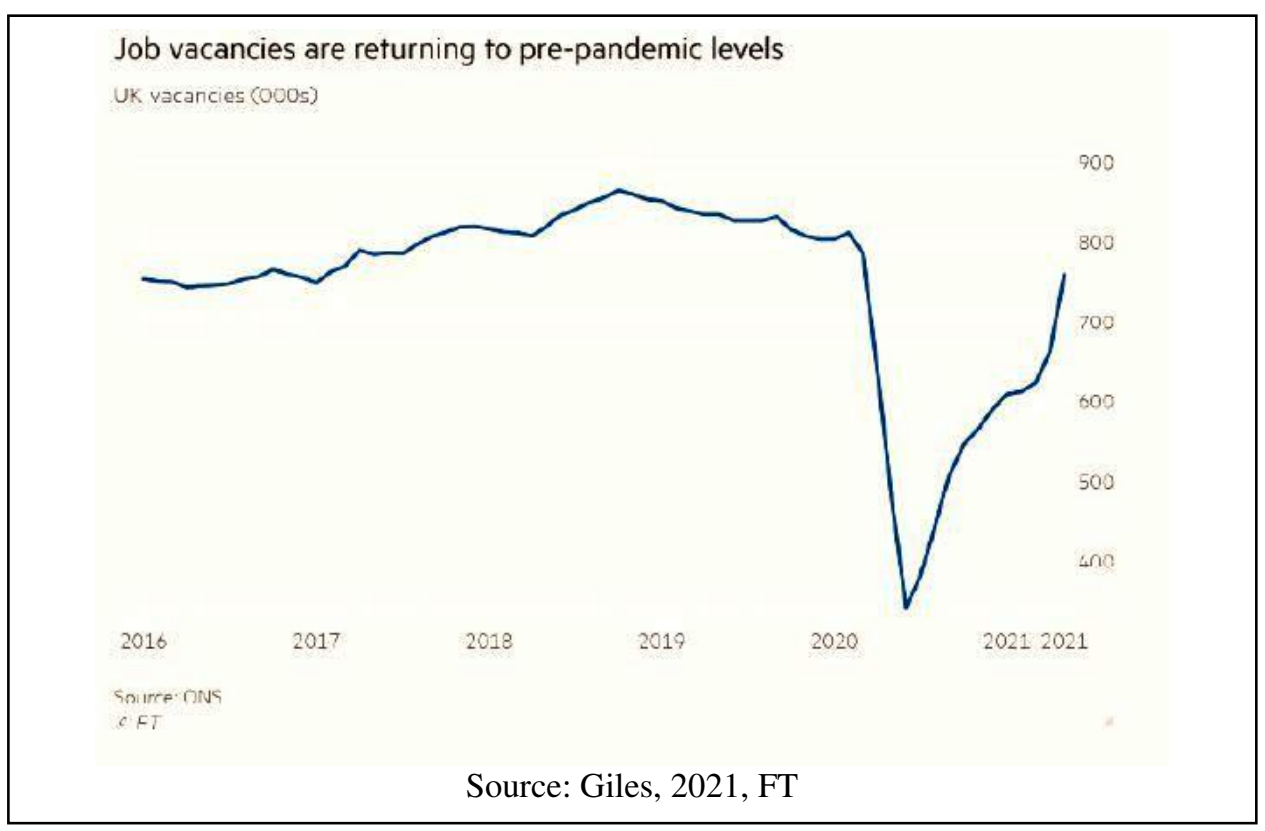

Advocates of the Brexit like Premier Boris Johnson claimed that leaving the EU would enable Britain to "take back control." But then, the benefits of Brexit for the UK are not evident either. London rapidly rolled over many trade agreements with countries that already had deals with the EU. The then foreign affairs minister, Boris Johnson, promised already before the Brexit vote in 2016 a 'titanic success' of the envisaged CANZUK union with the former white settler colonies of the British empire, meant to replace the lost EU market (Kohnert, 2021). However, economists are sceptical about the positive net effect of the deal. Even the British government's impact assessment suggested a total gain of just $0.02 \%$ in the long run (Giles, 2021).

Graph 3: Post-Brexit UK trade in goods with non-EU countries surpassed that with EU, $1^{\text {st }}$ quarter 2021

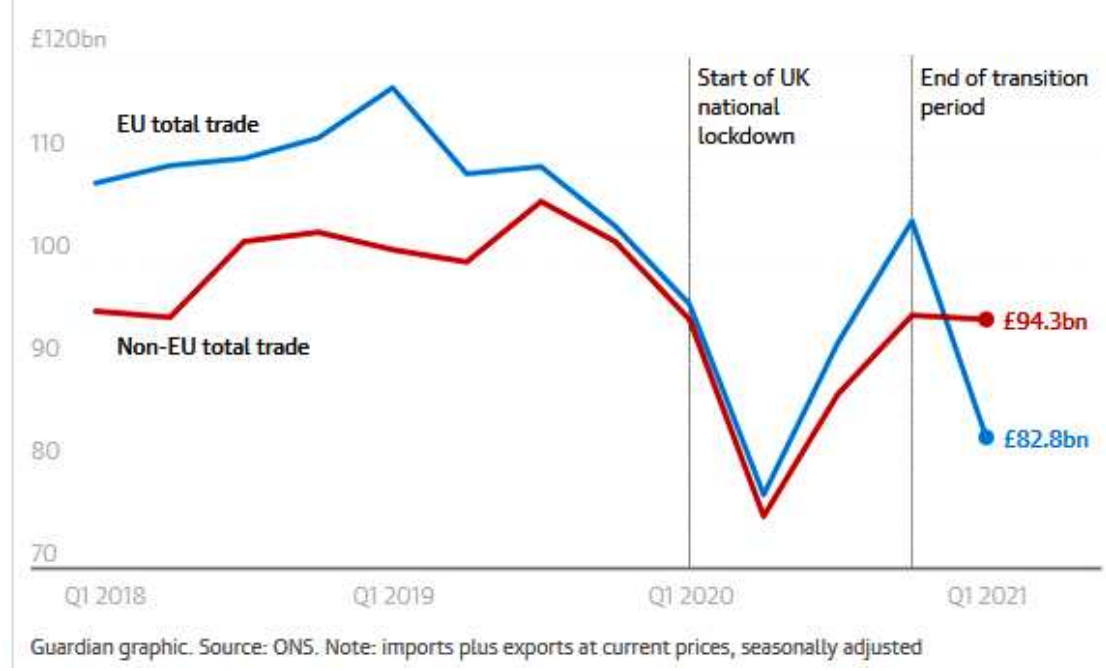

Source: The Guardian, Partington, 2021

However, recently the British got amazed about a perceived 'Corona miracle'. When Boris Johnson confirmed the end of almost all COVID-19 restrictions on 19 July 2021, gloomy 
forecasts were abounding. Epidemiologist Neil Ferguson from the Imperial College London, a member of the Covid advisory board SAGE, warned that an increase to 100,000 or even 200,000 new infections per day would be almost inevitable (Plickert, 2021). Yet, infections up to now did not increase substantially. On the contrary, at the beginning of August 2021, almost 22,000 new infections were reported and hospital admissions, as well as death, also increased only moderately since July. However, the question remains if the protection by the high vaccination rate of the British will last. Almost $73 \%$ of adults received two doses of the vaccine and $89 \%$ one dose. According to the British Office for National Statistics (ONS) in Newport, nine out of ten adults have antibodies against Covid, either because they have been vaccinated or have recovered.

Graph 4: Confirmed COVID-cases in the UK, March 2020 to July 2021

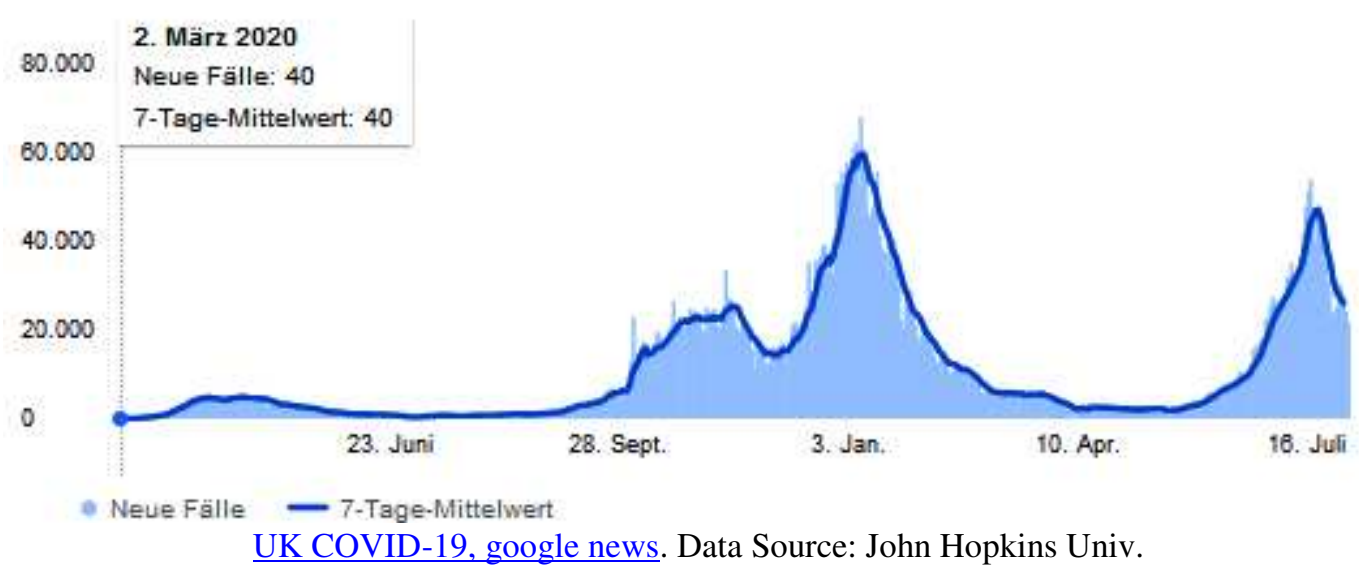

Moreover, the UK is likely to start a marvellous economic recovery. According to IMF forecasts Britain will show one of the world's highest growth rates with about $7 \%$ in 2021 . Thus, the pre-COVID-19 crisis level could be reached again by the end of 2021 according to the Bank of England (Plickert, 2021).

In the following, I should like to focus on the combined impact of Brexit and the COVID-19 pandemic on Israel and its Arab neighbours, one of the most virulent crisis regions of the world of long-standing. A political and socio-economic destabilization of these countries by the Corona crisis and post-Brexit effects could seriously impact the stability and security not just of the Middle-East region, but of the whole world. 


\section{The impact of Brexit and COVID-19 crisis on Israel}

\subsection{The impact of Brexit on Israel}

Cartoon 2: Prime Minister Boris Johnson's exit out of the EU

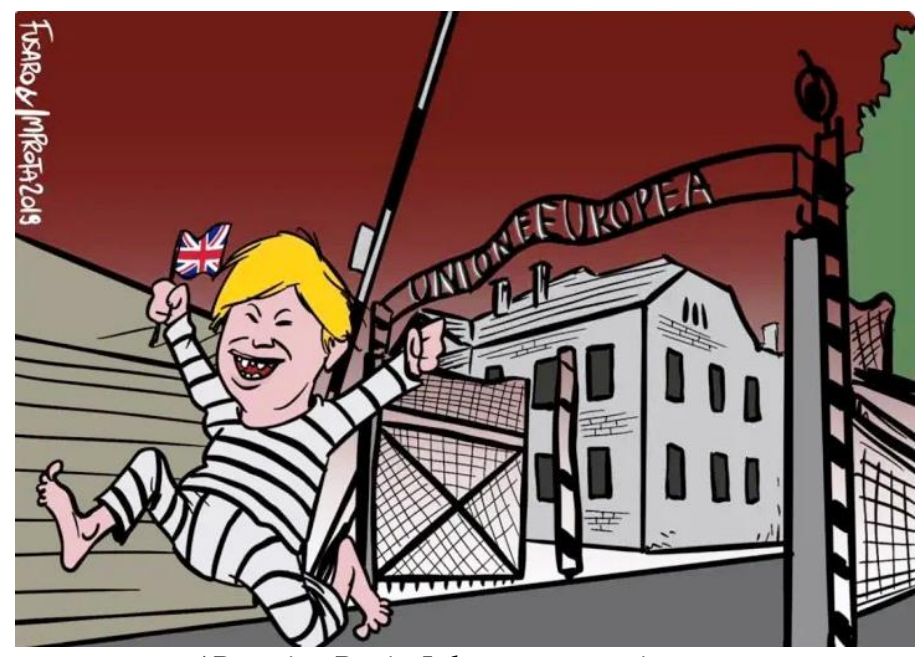

'Premier Boris Johnson as a prisoner,

excited to get out of the gates.of (EU) KZ-Auschwitz ${ }^{3}$

According to preliminary data, Brexit will have only a limited impact on Israel's economic relations with Britain (Miskimmon \& O'Loughlin, 2019). Bilateral Israel-UK trade, which amounted to about $£ 5.13$ bn (US\$ $7.01 \mathrm{bn} ; 22.8$ bn shekels)) in 2019 (Trade agreements of the United Kingdom, Wikipedia), had been governed by Israel-EU trade agreements. A new bilateral Israel-UK trade pact, which replaced the Israel-EU accord, was already agreed upon on 18 February 2019, coming into force on 1 January 2021 (ibid.; Cottrell, 2020).

However, Brexit could significantly change EU foreign policy towards Israel, which was hitherto generally perceived by Israelis as biased towards Palestine. When London still had influence in Brussels, it generally resisted diplomatic efforts from Paris and Berlin. The latter wanted EU foreign policy to implant a sustainable solution to the Israel-Palestinian conflict, based on two sovereign Arab and Israeli states. Britain, on the other hand, supported US diplomacy, favouring Israel, which was biased against a truly independent Palestine state. This was controversial given Britains historic responsibility as a former colonial power for the plight of Palestinians. Therefore, Palestinians and their Arab partners expect more from the renewed Global Britain than just empty words (Greene, 2019; Quilliam, 2021).

Yet, London's position as a close ally of Israel will probably be weakened by Brexit anyway. In case of Brexit triggering a decline of Britain's traditional role as mediator between Europe and the US, because Washington recognizes that London has had less influence in Brussels since it left the EU, this could also reduce the significance of British support for Tel Aviv (Jerusalem) $)^{4}$ to the detriment of Israel's supremacy in the Palestine region (Cottrell, 2020).

\footnotetext{
${ }^{3}$ Cartoon - Source. Jerusalem Post, 16 December 2019; screenshot from the Twitter account of Mario Improta

${ }^{4}$ The status of Jerusalem is disputed. Both Israel and Palestinians claim Jerusalem as capital. Most United Nations (UN) member states hold the view that the final status of Jerusalem should be resolved through negotiation. They, therefore, located their embassies in Tel Aviv prior to a final status agreement. However, in the late 2010s, Russia, the USA and Australia proposed that Jerusalem should be the future capital of both Israel and Palestine. This was endorsed by both the UN and the EU (Status of Jerusalem, Wikipedia). British Premier Johnson even asserted that US recognition of Jerusalem as Israel's capital was a "moment of opportunity" for
} 
Besides, because most economists, as well as scholarly economic literature, agree that Brexit is likely to harm the UK's economy, including a significant decrease in the UK's real per capita income in the medium and long term, Britain's influence on the international political scene is likely to fade too. As a consequence, the value of London's support of the Israeli regime will c.p. diminish, even if the UK would invest in a strengthened relationship with Israel (Cottrell, 2020).

Moreover, Brexit represents a worldwide trend to the revival of right-wing populist nationalism Donald Trump's policy of 'America first' was just the tip of the iceberg. Neither Israel, the UK nor the EU are exceptions to the rule. A growing proportion of the EU's population does not feel as European, but British, French, German, Dutch or Italian. They see Brussels as faceless administrative apparatus that has no intrinsic meaning and identity. Disappointed voters are increasingly inclined to vote for political rabble-rousers, like Nigel Farage, the leader of the British anti-EU party UKIP, Marine le Pen, leader of France's extreme right-wing National Rally (Rassemblement national), Björn Höcke, strong-man of the right-wing Alternative for Germany (AfD), Silvio Berlusconi, leader of the Forza Italia, and Netherland's Geert Wilders, leader of the Party for Freedom (Strenger, 2018).

Israel's right-wing populist political leaders, like former Premier Benjamin Netanyahu, who have been in power for most of the last forty years, also insist on national sovereignty, against outside political interference promoting universal liberal values. They hardly come up with a meaningful narrative over and above Jewish dignity and safety. Instead, they tend to fabricate existential dangers to keep their original narrative alive. Consequently, the level of hatred inside Israel between different political camps increased over time. Thereby the risk of deepening international isolation of Israel mounts, which again is used by the political right to heat baseless fears. The country's leaders lack of vision could even create similar but unintended effects to Brexit concerning the Jewish population. For example, the younger generation of American Jews, most of whom are liberal and cosmopolitan, increasingly disengage from an Israeli government, whose values they do not share any longer (Strenger, 2018).

Yet, the common accord on fundamental values of liberal democracy, like separation of powers, checks and balances, rule of law and a multi-party system, has so far been the foundation of the support of Western countries for Israel. If this base erodes, other global political players like Russia ${ }^{5}$, Turkey and Iran might intervene, not necessarily to the advantage of Israel and the welfare of Jewish people worldwide (Cottrell, 2020). Those Israeli leaders who claim that Brexit is in the country's interest are mistaken. Brexit just as continental European populism hardly constitutes an advantage, even not for conservative politics and Israel's national interest (Navon, 2019).

Meanwhile, the political discussion of the meaning of Brexit for Israel has been increasingly shaped by a 'domestication' of Brexit narratives as well as partisan national interests, notably by the political elite of the country. From a theoretical perspective, Brexit was 'glocalized' instead of constituting a global political event (Samuel-Azran \& Galily, 2018). Thus,

peace. Moreover, in June 2018, he accused the $\underline{\mathrm{UNHRC}}$ of focusing disproportionately on the Israeli-Palestinian conflict and Israel's occupation of the Palestinian territories (Boris Johnson (Wikipedia).

${ }^{5}$ According to a recent British Intelligence report, the publication of which was delayed for over a year probably out of political reasons, the Brexit decision by the British Upper House, was tainted by Russian influence, due to 'inappropriate links' between the House of Lords and oligarchs closely tied to the Russian regime (Siman-Tov \& Schulman, 2020). 
Johnson's ambitions to revitalize Global Britain by replacing the lost EU-market access with the new CANZUK union of former British white settler colonies (Canada, Australia, New Zealand) was heralded by the Israeli elite as the third major political force to emerge on the world stage. They expected post-Brexit relations with the Commonwealth world to improve considerably, and the connection of Israel with the CANZUK to become much sincerer than the cautious association established over the past decades between Israel and the EU (Teller, 2020). Yet, scholarly analyses reveal that instead of becoming a 'titanic success', as propagated by Boris Johnson, CANZUK will probably develop little value-added neither to British nor to Israeli foreign trade and diplomacy (Kohnert, 2021; 2021a).

\subsection{The socio-economic impact of the COVID-19 crisis on Israel}

Graph 5: Confirmed COVID-cases in Israel, March 2020 to July 2021

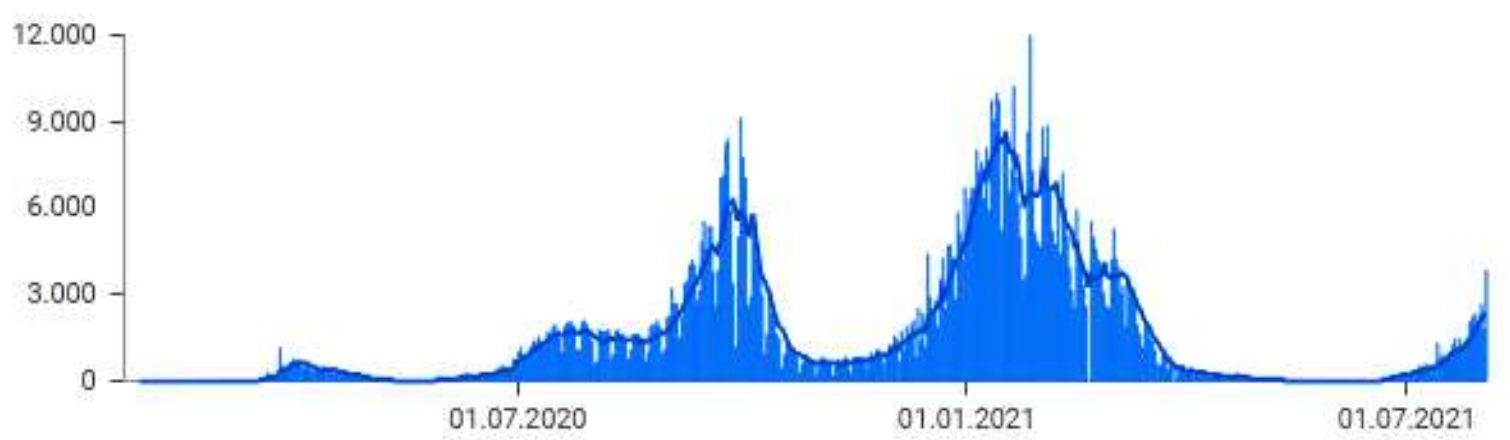

Israel, COVID-19, google news, data source: John Hopkins Univ.

Graph 6: COVID-19 crisis affecting living standards, Israel, 1999-2020

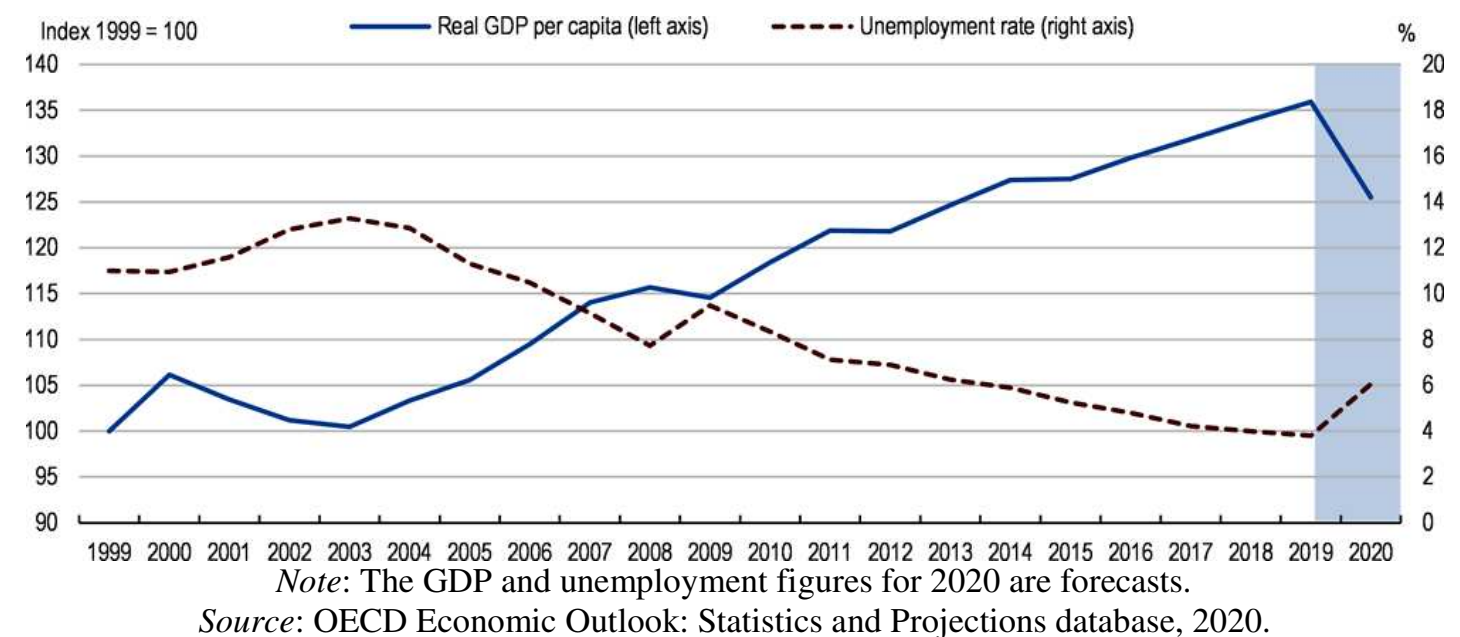

OECD Economic Surveys: Israel 2020

The COVID-19 pandemic coincided with Israel's domestic political crisis (2019-2021), i.e. the government collapse, triggering the fourth election in two years. The country's first casualty on 20 March 2020 was paradoxically an 88-year-old Holocaust survivor from Jerusalem (COVID-19 pandemic in Israel, Wikipedia). After the outbreak of the pandemic, the government introduced stringent confinement measures, including an early closure of 
borders, restricting mobility, gathering and workforce controls. This helped to limit new infections during the first wave of the pandemic. Unfortunately, the pandemic resurged after the economy was largely reopened in June 2020. This requiring renewed tightening of confinement measures and finally a second nationwide lockdown in September, the world's first second general lockdown. Thus, the pandemic threatened to reverse some of the achievements made over the last decade in improving Israel's standards of living that had risen close to the OECD average (OECD Economic Surveys: Israel 2020).

Graph 7: Israel's labour market weakened substantially, Feb. 2020 to Jul. 2020

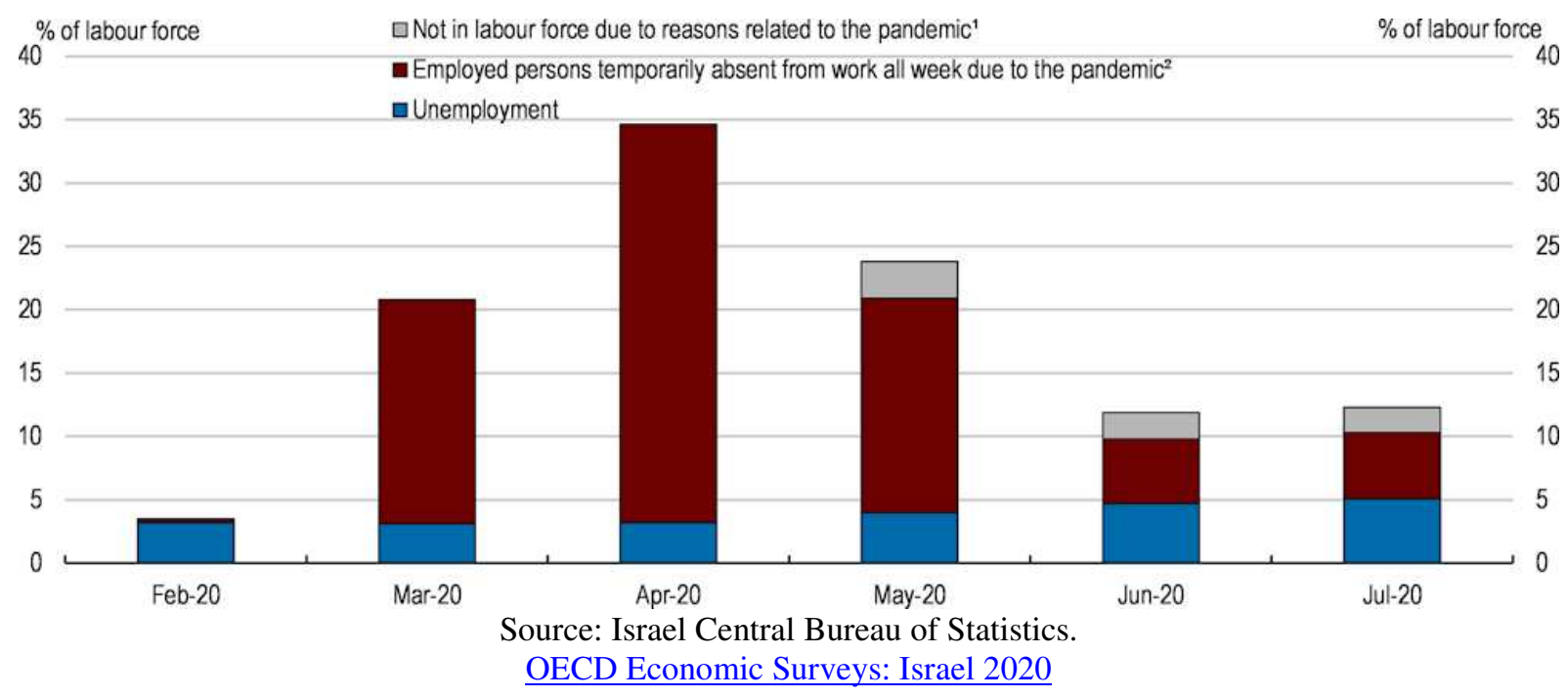

But average statistics have only limited explanatory power because Israel remains a dual, twospeed economy. A vital high-tech sector is compensated by lagging shielded sectors, employing most of the workforce. Therefore, income inequality remains large and growing. Poverty is widespread, especially among Arab-Israelis and Haredim, the latter largely out of their own choice, i.e. because they focus on non-material benefits and engage in life-long religious studies. Not for nothing, infection rates were higher in several Ultra-Orthodox and Arab towns and neighbourhoods. In the second, more severe wave of the pandemic, death rates were negatively associated with socioeconomic status and the size of the elderly population and positively with communities' population density. In short, the pandemic particularly affected marginalized communities characterized by low socio-economic status and high residential density (Birenbaum-Carmeli \&Chassida, 2021).

As for Israel in general, the Government's COVID-19 vaccination campaign which started on 19 December 2020, was speedy and a third lockdown was implemented on 8 January 2021. As of 26 June 2021, about $64 \%$ of entitled Israelis had received at least one and $60 \%$ the required two doses, making it the country with the highest vaccination rate in the world per capita. This demonstrated the significant effect of a thorough national vaccination campaign on the pandemic dynamics (Rossman et al., 2021). One reason for the success was the centralization of the Israeli government and is lacking concern about civic data protection. Thus, at the start of the vaccination campaign, it agreed for example with Biontec vaccine provider Pfizer to share medical information about its citizens as part of a deal to receive preferential access to COVID-19 vaccines (COVID-19 vaccination in Israel, Wikipedia). Thus, the death toll in Israel had been lower than in the hardest-hit OECD countries (OECD Economic Surveys: Israel 2020). 
Graph 8: Macroeconomic COVID-19 related developments, Israel, 2010-2020
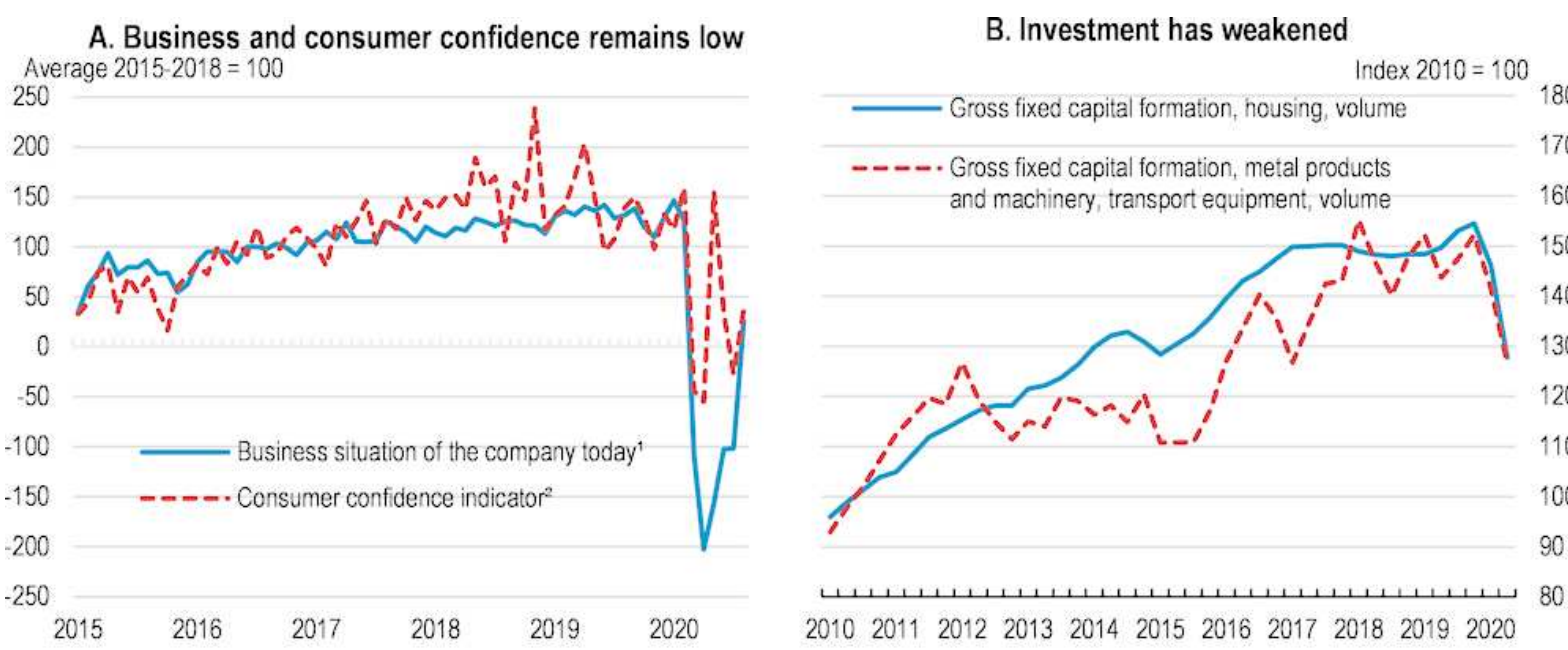

C. Export performance has recovered moderately

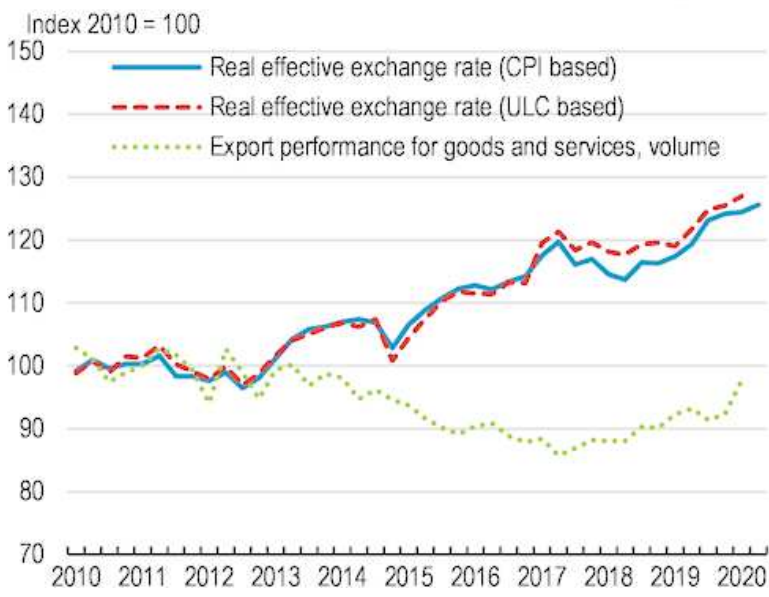

20102011201220132014201520162017201820192020

D. Main impediments to manufacturing sectors ${ }^{3}$

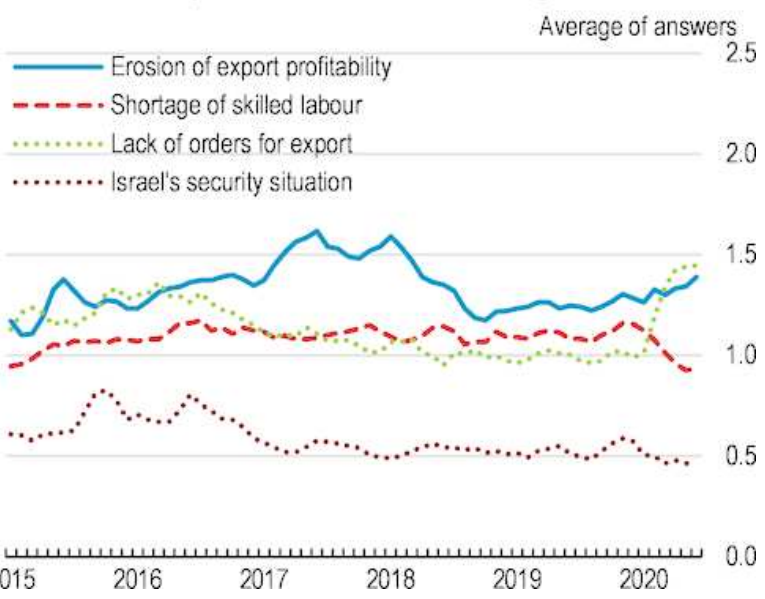

Source: OECD Economic Outlook: Statistics and Projections database; Israel Central Bureau of Statistics OECD Economic Surveys: Israel 2020

\subsection{The socio-economic impact of the COVID-19 crisis on Palestinians in Israel}

Because of Britain's particular historic responsibility as a former colonial power for the fate of the Palestinian people, the latter, as well as other Arab countries and Human Rights groups demanded increased assistance of the UK in the ongoing COVID-19 pandemic. Arab Palestinians constituting over one-fifth of Israel's population. They are divided into a Muslim majority (about 84\%) and a Christian and Druze minority (each comprising 8\%). These groups significantly differ in their social and economic characteristics. The pandemic was not only a health issue but also exacerbated socio-economic inequality between these groups.

Palestinians on top of the wage distribution were more likely to be still employed compared to ordinary Palestinian workers. However, while Jews in the bottom of the income distribution were more likely to work in the service industry, Arabs in the same position were more likely to work in occupations less vulnerable to pandemic-induced lockdown measures, such as construction and agriculture, with subsequent repercussions for their income. Another departure from the general Israeli population was the absence of significant gender differences within the Palestinian population (Miaari, et al, 2020). 
Map 1: Palestine partition with economic union

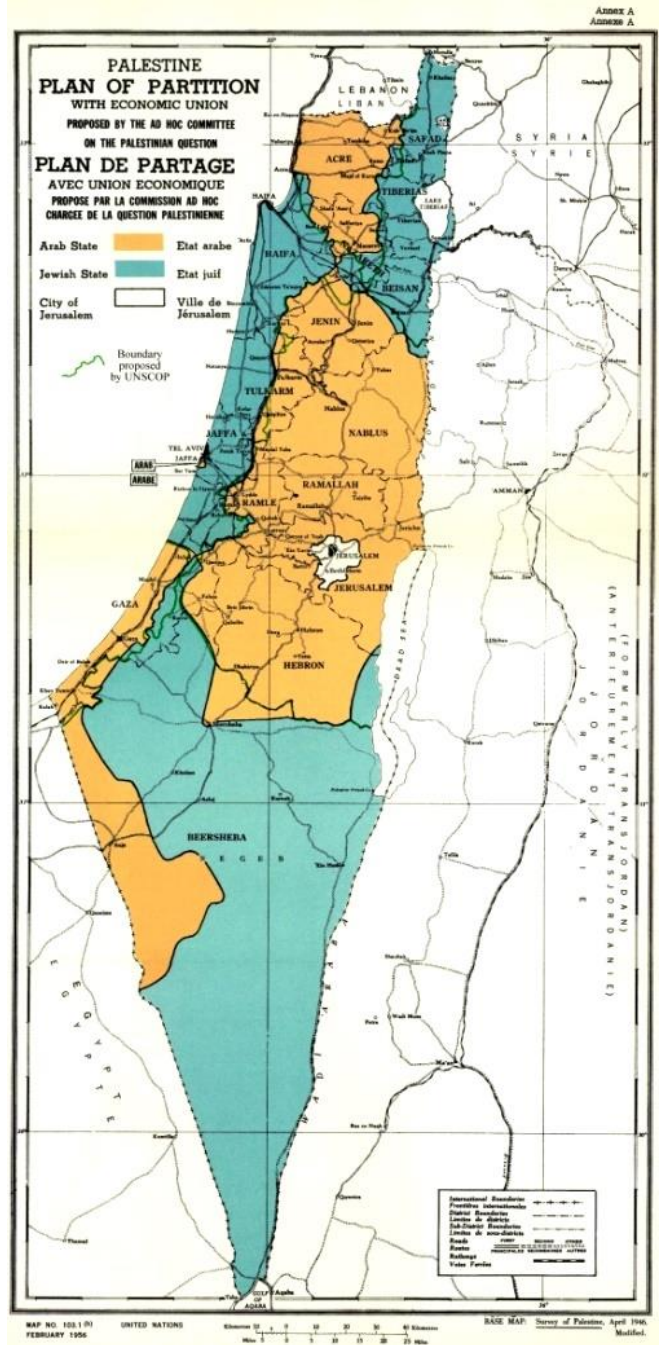

February 1956 Map of UN Partition Plan for Palestine, adopted 29 Nov 1947, boundary of previous UNSCOP partition plan added in green. Source: Israel, Wikipedia

Yet, the Occupied Palestinian Territory $(\mathrm{oPt})$ was especially hard hit by the pandemic. Already before its start, high poverty and unemployment rates had persisted and GDP per capita declined for the third consecutive year. Forecasts for the Palestinian economy for 2020 and 2021 were miserable, with GDP per capita projected to decrease by a further $3 \%$ to 4.5 $\%$.

The West Bank recorded its lowest growth rate since 2012 (1.15\%), while the Gaza strip's growth amounted to zero as it failed to recover from the two consecutive GDP contractions of $-7.7 \%$ and $-3.5 \%$ in 2017 and 2018 respectively (UNCTAD, 2020). This alarming development was again aggravated by restrictions and leakage of fiscal resources that continued to undermine the Palestinian economy. According to UNCTAD estimates, the annual leakage of Palestinian fiscal resources to the Israeli treasury amounted to $3.7 \%$ of GDP or $17.8 \%$ of total tax revenues. Moreover, a new annual deduction of US\$ $144 \mathrm{~m}$ from Palestinian clearance revenues had been put in place in March 2020 as an equivalent to the payments made by the Palestinian National Authority (PNA) to families of Palestinians in Israeli prisons or killed in attacks or alleged attacks against Israelis. The unemployment rate increased from $31 \%$ in 2018 to $33 \%$ in 2019 and the poverty rate from $25.8 \%$ to $29.2 \%$ between 2011 and 2017. The volatile situation of the occupied territories was again 
aggravated by Jewish annexation. By the end of 2018, there were 150 Jewish settlements and 128 outposts in the West Bank, in flagrant violation under international law according to the UN Security Council. In the Gaza strip, even $80 \%$ of the population depended on volatile international assistance.

The COVID-19 pandemic still deepened the plight of the Palestinian people. Revenues collected by the PNA from trade, tourism and transfers declined to their lowest levels in 20 years just a month after the outbreak. Forecasts on the cost of the pandemic ranged between $7 \%$ to $35 \%$ of GDP, depending on assumptions about the severity and duration of the pandemic (UNCTAD, 2020).

\section{Impact of Brexit and COVID-19 crisis on Lebanon}

\subsection{The impact of Brexit on Lebanon}

Lebanon is governed by a corrupt and greedy political class. Political power is distributed among the elite according to the major religious groups, Christians, Sunni- and ShiiteMuslims, and Druze (Ehrhardt, 2021).

Graph 9: Lebanon religious groups, regional distribution

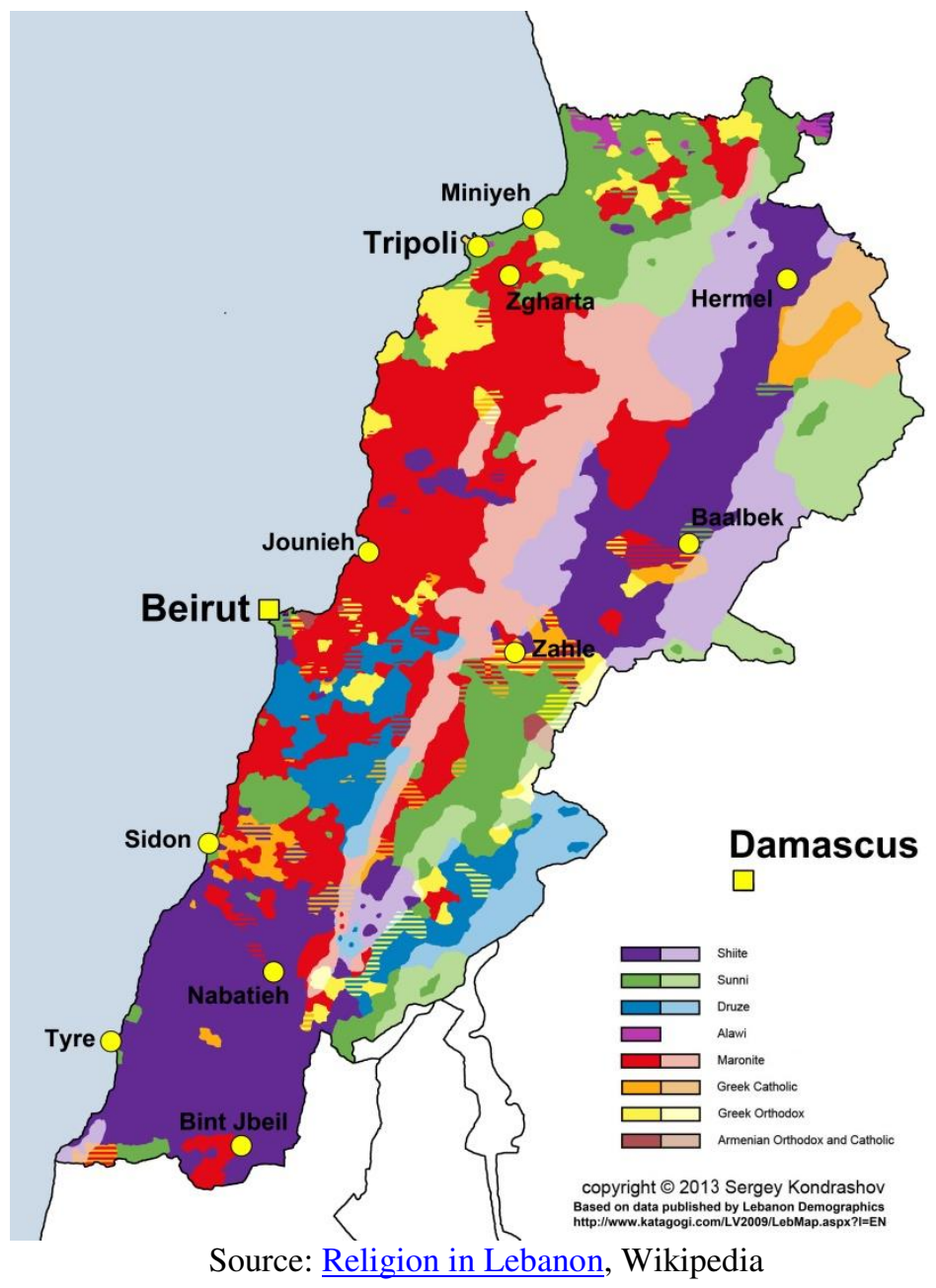


Graph 10: Distribution of religions in Lebanon

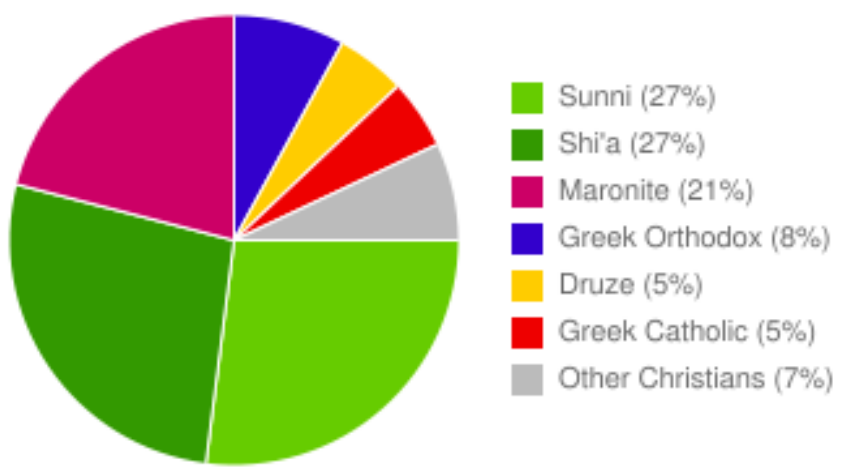

Source: based on 2010 State Department data, Lebanon, Wikipedia

The UK is only a minor economic player concerning Lebanese foreign trade and investment. Lebanon was the UK's 92nd largest trading partner in 2020, accounting for less than $0.1 \%$ of total UK trade. Total bilateral trade amounted to $£ 560 \mathrm{~m}$ in 2020 , a decrease of $32.4 \%$ compared with 2019. Thereof, exports to Lebanon totalled $£ 435 \mathrm{~m}$, a decrease of $33.9 \%$, and imports $£ 125 \mathrm{~m}$, a decrease of $26.9 \%$. The decrease was probably mostly due to the global economic effects of the Corona crisis and not to Brexit. British outward stock of foreign direct investment (FDI) in Lebanon summed up to $£ 265 \mathrm{~m}$ in 2019, the inward stock of FDI $£ 15 \mathrm{~m}$ (Trade and Investment factsheet, Lebanon, DIT, London, 2021). Nevertheless, London ratified a Post-Brexit already 2019 trade and association agreement with Beirut (Lebanon, DIT, 2021).

On the other hand, around $30 \%$ of Lebanon's imports US \$ 6 bn, come from the EU and the presumed decline in the Euro because of Brexit would cut the country's import bill. While a huge percentage of imports come from the EU, Lebanon only exports about $15 \%$ of its own products to Europe. According to Lebanese economists, Brexit will benefit Lebanon in the first and short term, because a weaker Euro and Pound Sterling would reduce Lebanon's import bill, as the Lebanese pound is pegged to the U.S. dollar (Halawi, 2016). A predicted drop in oil prices, also as a result of the Brexit vote, would impact positively because the trade deficit would go down and the balance of payments improve accordingly because oil and fuel make up Lebanon's largest imports. Furthermore, according to Lebanese economists, the presumed surge in gold prices, following Britain's Brexit vote, would have a positive impact, because Lebanon's Central Bank has the second-largest gold reserves in the Middle East and North Africa (MENA) region, i.e. about 9 million ounces of gold reserve of a market value of over US\$ 12 bn. Negative effects would only affect Lebanese investors in the real estate and stock markets in the U.K. (Halawi, 2016).

\subsection{The socio-economic impact of the COVID-19 crisis on Lebanon}

The impact of the COVID-19 pandemic in Lebanon has to be evaluated, taking into account the ongoing Lebanese economic crisis and its following socioeconomic results that accelerated in October 2019, when the Lebanese pound lost $78 \%$ of its value. The loss of jobs, lacking family support and diminishing UN funds led to the worsening of living conditions and increased poverty. The deprivation did not strike just the Lebanese population but particularly the large proportion of Syrian and Palestinian refugees living in the country, equivalent to $21.7 \%$ and $6.7 \%$ of Lebanese total population respectively (Hajjar \& AbuSittah, 2021). Lebanon has one of the highest refugee populations in the world with 209 
refugees per 1,000 inhabitants in 2015. According to the UNHCR 2020 vulnerability assessment, $89 \%$ of Syrian refugee families in Lebanon lived below the extreme poverty line, up from $55 \%$ in mid-2019 (UNHCR, Lebanon, 2021). All this was further exacerbated by both the socio-economic effects of the 2020 Beirut port explosion and the ongoing COVID-19 pandemic in Lebanon that began in February 2020. During the pandemic refugees' mobility was restricted by very strict and control-led preventive mechanisms as a consequence of already stretched and problematic health and socio-economic systems (Moawad \& Andres, 2020).

Graph 11: Confirmed COVID-cases in Lebanon, July 2020 to July 2021

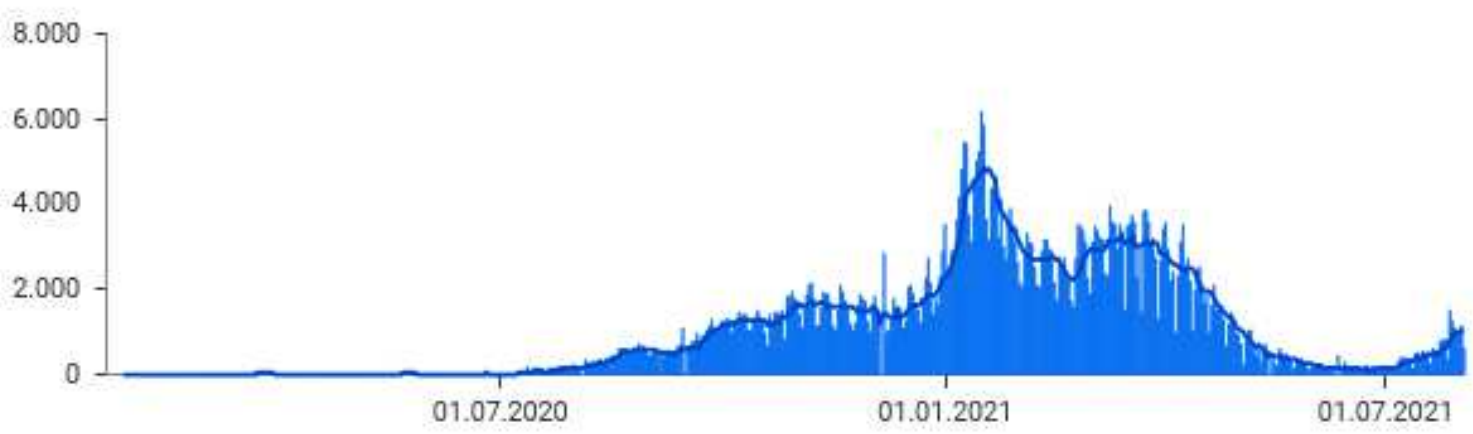

Lebanon, COVID-19, google news, Data source: Johns Hopkins University

Whereas Beirut had handled the pandemic successful in the beginning, cases skyrocket after the Beirut port explosions on 4 August 2020, with over 1,000 cases on most days since midSeptember. Already on 10 July 2020, the UNHCR had raised alarm on the dire effects of the suffocating Lebanese socio-economic crisis which left Lebanon's poor with little or no means to cope with extra hardship. According to UNHCR figures, an estimated $75 \%$ of Lebanon's population needed aid. Alongside the refugees, the country hosted more than 250,000 migrant workers, many of which lost their jobs, were no longer paid and were left homeless. Moreover, they were no longer able to send remittances to their families back home. According to the official figures of the Beirut' government, there were 401,826 confirmed cases and 5,134 death (fatality rate of $1.27 \%$; as of March 10, 2021; COVID-19 pandemic in Lebanon), which was probably a gross underestimation.

Not only physical but also mental health problems increased significantly as a consequence of the combined effects of the pandemic, a collapsing economy and political turmoil (Salameh et al; 2020; Hajjar \& Abu-Sittah, 2021). Higher stress and anxiety affected particularly younger adults, women, and persons with previous higher socio-economic status, having a family member with a chronic disease, fear of not getting access to treatment, fear of COVID-19, and physical violence at home. Those below the poverty line before the Corona crisis showed also significantly higher stress and anxiety. The middle- and long-term impact could result in alarming consequences, including mounting psychiatric illnesses, alcohol-related disorders, illicit drug use and suicide rates (Salameh et al; 2020). 


\section{The impact of Brexit and the COVID-19 crisis on Jordan}

\subsection{The impact of Brexit on Jordan}

The UK has been a central economic and security player in Jordan that, as a former British colony - has strong historical ties to the UK. Thus, Jordan is reliant for example on British capital concerning tourism and on aid (Chaban et al, 2020). London ratified a trade agreement with Jordan in 2020 (UK trade agreements with non-EU countries: DIT, 19 July 2021).

Total bilateral trade in goods and services was $£ 591 \mathrm{~m}$ in 2020 . Thereof, total UK exports to Jordan amounted to $£ 464$ million, an increase of $1.1 \%$ or $£ 5 \mathrm{~m}$. Total UK imports summed up to $£ 127 \mathrm{~m}$, a decrease of $3.8 \%$ or $£ 5 \mathrm{~m}$ from the year before. Jordan was the UK's 89th largest trading partner, accounting for about $0.1 \%$ of total UK trade. In 2019, the outward stock of FDI from the UK in Jordan added up to $£ 11 \mathrm{~m}$, the inward stock in the UK was $£$ $239 \mathrm{~m}$ (Trade and Investment factsheet, Jordan, DIT, London, 2021).

London will try to preserve its special relationship derived from colonial times, last but not least, to maintain privileged access to Jordan's military and security markets. Amman is a huge buyer of weapons and invests a lot of capital in British financial markets. London's decision in November 2020 to reduce foreign aid and increase defence spending could be part of an aggressive effort by London to sell weapons.

Thus, Britain's and Jordan's renew security cooperation resulted in a new three-year phase of support to Jordon's Public Security Directorate (PSD) and the Gendarmerie. The support valued more than $£ 10 \mathrm{~m}$, is likely to include counterterrorism, public order management, and core policing (Walsh, 2019). Additionally, the Jordan CSSF - Defence and Borders program (2019-20), a British non-ODA program building on the long-standing bilateral military cooperation, supported a cross-section of the Jordanian Armed Forces (JAF) to become more effective, notably against Counter-Terrorism, including the upgrading of a Quick Reaction Force (QRF) to a Brigade (MoD, 2019).

However, this British security aid focus was controversial. According to a recent Arab Barometer survey, the great majority of Jordan's population would have preferred economic aid, whereas counter-terrorism was only a priority for $2 \%$ of Jordan voters because they were quite satisfied with their police. For example, Jordan has experienced since 2016 fewer domestic fatalities from terrorism than in the U.K. Yet, according to the official view, Britain's. support to the Jordanian security sector during the past two years was not disproportionate. It totalled $£ 58.6 \mathrm{~m}$, thereof $£ 28 \mathrm{~m}$ economic support. The latter would augment to about $£ 50 \mathrm{~m}$ if aid-project with basic economic characteristics, like education, employment, and humanitarian projects would be included (Walsh, 2019).

Yet, the ongoing economic crisis resulted in mounting popular protests with an increasing level of tension, including the middle-class which was progressively affected by economic hardship, especially in Amman. Corruption in virtually all government institutions, which is growing since 2010 in popular perception, constituted another driver of popular protest and demonstrations (Walsh, 2019).

Arguably, the EU's role in Jordon could diminish, and EU members, like France and Germany, be tempted to adopt a less interventionist strategy in the Middle East, e.g. by assessing regional security and stability over democratisation (Yeung, 2020). However, the 
EU continued to aid Jordan within its MFA good-governance and COVID-19 assistance programs to help Jordan mitigate the economic and social impact of regional conflicts and the presence of a large number of Syrian refugees. It disbursed $€ 250$ million in macro-financial assistance (MFA) to Jordan in 2021 as part of the $€ 3$ bn emergency MFA package for ten enlargement and neighbourhood partners, and partly from Jordan's $€ 500 \mathrm{~m}$ third MFA programme (MFA-III) approved in January 2020 (EU, 2021).

\subsection{The socio-economic impact of the COVID-19 crisis on Jordan}

As of early August 2012, there were a total of 772,000 confirmed COVID-19 cases and 10,048 death. Fully vaccinated were 2.260 .376 persons, i.e. $21.2 \%$ of the total population (Jordan: COVID-19; google.news; Source of data: Wikipedia, Johns Hopkins University).

Graph 12: Confirmed COVID-cases in Jordan, April 2020 to July 2021

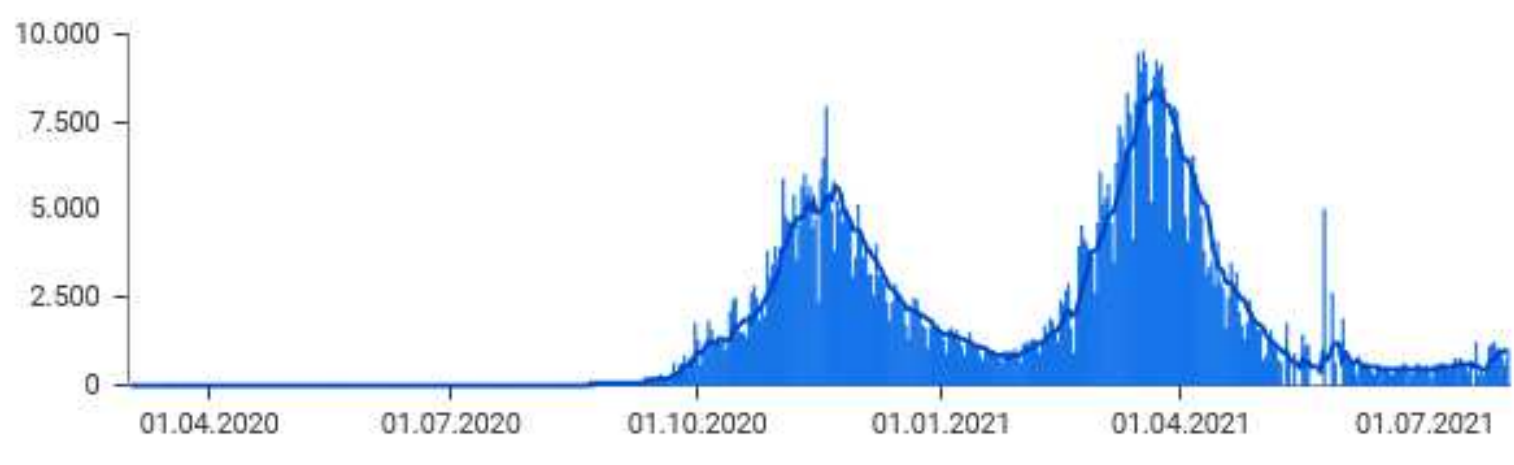

Jordan: COVID-19; google.news (Source of data: Wikipedia, Johns Hopkins University )

Jordan's National Epidemics Committee and Health Ministry reacted quite early to the news of the global spread of the pandemic. Already on 26 January 2020, it designated certain hospitals to treat infections, five weeks before the country recorded its first case on 2 March (COVID-19 pandemic in Jordan, Wikipedia). This was followed by a first lockdown on 17 March, which was later modified into a curfew, one of the strictest in the world according to international experts. But this resulted only in a delayed first pandemic wave. There was a dramatic and sudden surge in COVID-19 cases and deaths since September 2020. Thereupon, Amman declared a nationwide curfew on Fridays and Saturdays. Still, Jordan became the Arab country with the highest number of COVID-19-related deaths per capita in October. Yet, the parliamentary election was held in person.

The vaccination program started in December, including the high proportion of refugees in the country. Thus, Jordan was one of the first countries to include this particularly vulnerable social group, as reported by the UNHCR on 14 January 2021 (COVID-19 pandemic in Jordan, Wikipedia). Nevertheless, all this could not stop the spread of the pandemic effectively. After the first wave of October-December 2020, there was a second, even more severe wave in April 2021. Until May 2021 the country had passed through three distinct pandemic stages (Al-Tammemi et al, 2021). Pandemic fatigue and vaccine hesitancy counted among the most challenging issues worsening the pandemic. However, given the negative life-threatening economic consequences, most concerned persons of the lower social strata, e.g. daily labourers, unemployed and small self-employed, notably the poor and most vulnerable, had little choice, concerning the observance of the strict anti-Corona measures. 
Also in Jordan, the COVID-19 pandemic imposed a significant level of psychological stress on the population. Women of the lower and middle class and nurses as well as those who had close contact with COVID-19 patients suffered the most. Given the stigma surrounding mental health in Jordan, the general lack of mental health awareness, transportation and financial costs, which all constituted significant barriers for utilizing mental health services, this is particularly noteworthy (Khatatbeh, et al, 2021).

According to an ILO / UNDP survey of enterprises in Jordan in late April 2020, $51 \%$ of the surveyed enterprises had closed temporarily already at the beginning of the pandemic. On average of $42 \%$ of enterprises indicated that they would be able to continue paying salaries for less than one month, another $42 \%$ for less than three months. On the contrary, $44 \%$ of small enterprises and $55 \%$ of micro-businesses said that they lacked the means to keep paying any salaries, while medium (33\%) and larger enterprises $(23 \%)$ were more likely to be able to pay salaries for an additional month. Almost $40 \%$ of mostly smaller enterprises stopped payment to social security, making use of the waver introduced by a government defence order (Kebede, et al, 2020).

\section{The impact of Brexit and the COVID-19 crisis on Egypt}

\subsection{The impact of Brexit on Egypt}

Cartoon 3: British Premier Theresa May on Brexit

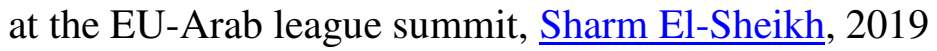

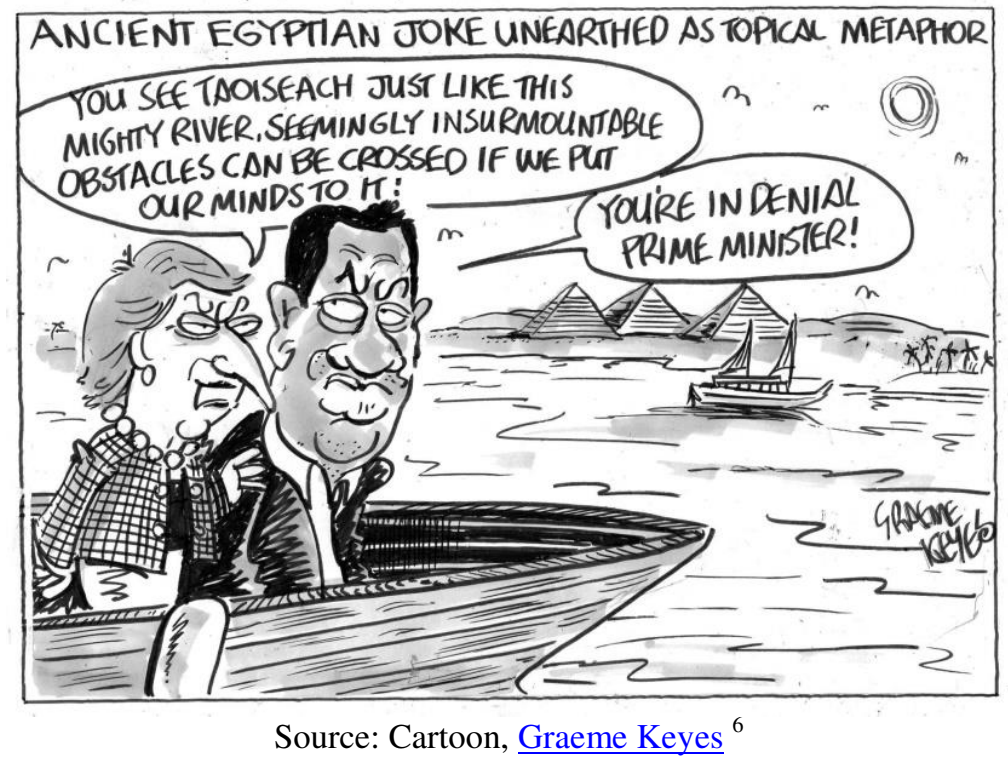

Egypt and Britain have longstanding strong relations in the political, defence, trade, and investment sectors. Therefore, both established a trade association end of 2020. The treaty

\footnotetext{
${ }^{6}$ Political cartoon gallery, London and·twitter.com, \#Brexit, \#TheresaMay, \#BrexitExtension, 25 February 2019. The Irish word Taoiseach means "leader". - Allusion to Prime Minister Theresa May's last-minute decision to attend the first-ever EU-Arab league summit (24./25. Februar 2019) in Sharm El-Sheikh, Egypt, under the cochairmanship of Egypt's President Abdelfattah Al Sissi. Although Brexit was not on the agenda officially, also the roots of the Brexit vote, like migration, security, stability and terrorism, had been discussed. Given the implications of Brexit and rising populist nationalism in the EU, the attending European leaders deliberately overlooked the autocratic image of Al Sissi (Robertson, 2019).
} 
was presented to Parliament in December 2020 (UK trade agreements with non-EU countries: DIT, 19 July 2021). It entered into force on 1 January 2021 after the UK ended the transition period to leave the EU. It safeguarded the same advantages that had been provided by the Egyptian-European free-trade agreement. The British International Trade Secretary, Liz $\underline{\text { Truss, }}$ underlined that London remained committed to securing deals supporting British jobs, deliver significant savings and help drive the post-COVID-19 recovery. The agreement provided tariff-free trade on industrial products, liberalization of trade in agriculture, agrifoods and fisheries and was meant to present considerable savings to businesses in both countries (Kotb, 2020; N.A., 2020). Moreover, the Egyptian Foreign Ministry stated that the two sides had pledged to achieve greater free trade in agricultural goods in the future, which, however, would be difficult to justify vis à vis the British farmers. Agricultural products and textiles had represented each $15 \%$ of Egyptian exports to the UK in 2017, followed by electric equipment and crude oil with $26 \%$ and $18 \%$, respectively. As part of a national strategy to develop Egypt's industry, Cairo was planning to quadruple textile and garment exports by 2025. Considering that clothing was the UK's fourth-biggest import in 2018, accounting for $4.1 \%$ (US\$ $24.5 \mathrm{bn}$ ) of total British imports, this could outstrip crude oil imports by around US\$ $493 \mathrm{~m}$ (Moslem, 2019). The agreement, which entered into force on 1 January 2021 after the United Kingdom ended the transition period to leave the European Union, ensured the continuity of preferential access to both markets as it secures the same advantages that have been provided by the Egyptian-European free-trade agreement.

As of 30 July, 2021 total trade in goods and services (exports plus imports) between the UK and Egypt was $£ 2.7$ bn in 2020, a decrease of $18.1 \%$ or $£ 605$ million from the year before (Trade and Investment factsheet, Egypt, DIT, London, 2021). Therefore, total UK exports to Egypt amounted to $£ 1.8$ bin, a decrease of $9.6 \%$ or $£ 194 \mathrm{~m}$. Major goods exports to Egypt from the UK in 2019 included metal ores ( $£ 235$ million) and medicinal and pharmaceutical products ( $£ 111$ million). Total UK imports from Egypt summed up to $£ 917 \mathrm{~m}$, a decrease of $30.9 \%$ or $£ 411 \mathrm{~m}$. Probably most of the decrease was due to the global economic effects of the Corona crisis, as for the immediate Brexit effect there were to expect mainly logistical challenges. Egypt was the UK's 50th largest trading partner accounting for $0.2 \%$ of total UK trade. In 2019, the outward stock of FDI from the UK in Egypt was not available due to data disclosure. However, in 2016/17 the UK represented $41 \%$ of total FDI inflows into Egypt, totalling about US\$ 5.4 billion, distributed over about 1,570 projects across multiple sectors. This showed the importance of British investments to the Egyptian market, considering that the UK ranks fifth worldwide in outward FDI with about US\$ 1.6 trillion, and third in terms of inward FDI at \$1.65 trillion. In 2018, London had agreed for example to provide a record US\$ 1.6 bn to Carbon Holdings to participate in financing the Tahrir Petrochemicals Complex (TPC), the region's largest petrochemicals complex built in the Suez (Canal) Economic and Trade Cooperation Zone (Moslem, 2019). The inward stock of FDI in the UK from Egypt was $£ 20 \mathrm{~m}$ (Trade and Investment factsheet, Egypt, DIT, London, 2021).

The Egypt business and the Egyptian-British Chamber of Commerce (EBCC) were overwhelmingly in favour of Brexit (Mehling, 2016; El-Shimy, 2017; Moslem, 2019). Although Egypt's economists conceded that the economic ramifications would take time to be visible, they were convinced that in the short run it would benefit Egypt's import-driven economy, particularly in terms of the balance of payment and budget deficit. Because the pound sterling and eventually also the Euro were expected to devalue, imports, notably cars, pharmaceutical products, industrial chemicals and consumer goods, from the UK and the EU would become cheaper. Moreover, devaluation would have a positive effect on Egypt's external debt and balance of payments. Besides, experts predicted capital flight out of the UK and diminished purchasing power in the EU and UK because of the overall negative economic 
effects of Britain leaving the EU. All this could affect Egypt's FDI, stock exchange, Suez Canal revenues, foreign currency borrowing, tourist revenues, and expatriate remittances. In case British tourists to Egypt, which counted about 200,000 p.a. before 2016, a number that had doubled to about 415,000 British in 2018 (Moslem, 2019), would remain at home because they had to curb expenditure because of negative effects of Brexit on their income and because of a devaluation of the British pound, the Egyptian tourism industry would be severely hit, travelling becoming more expensive to Britons (Allam, 2016). The same applies to tourists from Germany and France. Moreover, European tourists could avoid Egypt because of the mounting fear of terrorist attacks. FDI was expected to remain largely unchanged or even to increase both from the UK and the EU-27 because the latter tried to stop their migrant crisis by strengthening North African countries (Mehling, 2016).

Graph 13: Egypt - EU-27 trade in goods and services

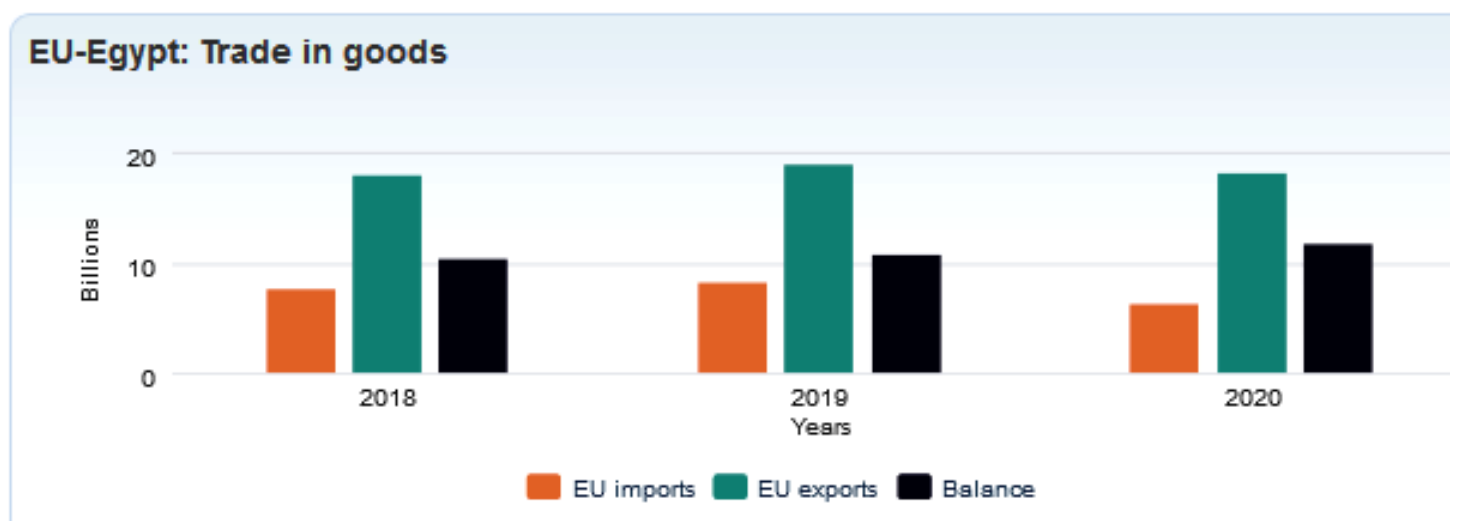

EU-Egypt: Trade in services

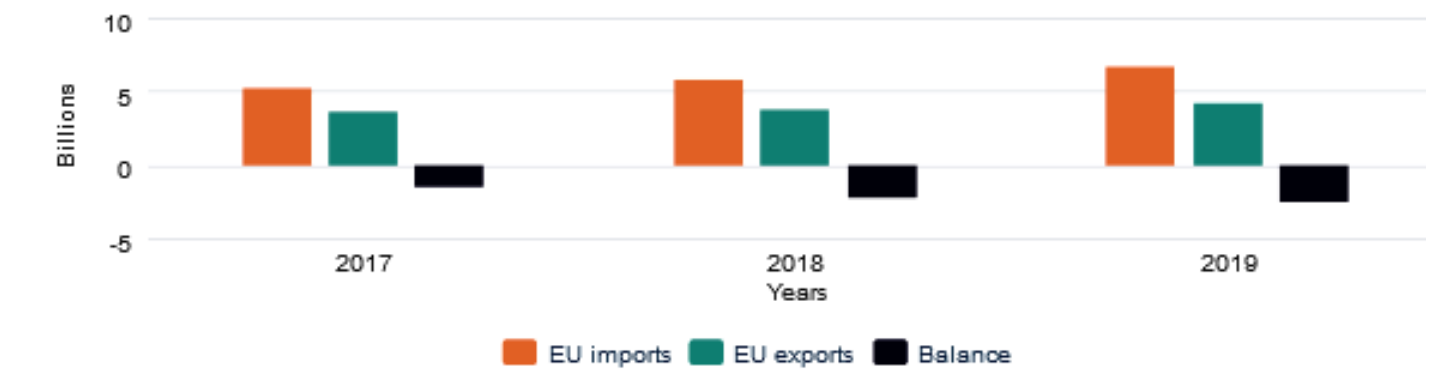

EU-Egypt: Foreign direct investment

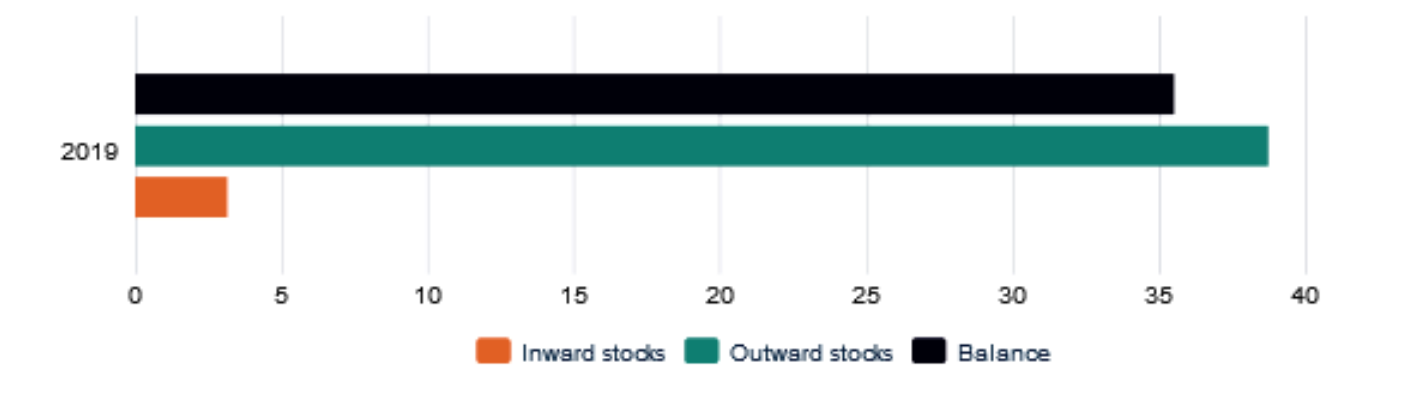

Unless otherwise mentioned " $E U^{x}$ concerns for all indicated years the current European Union of 27 Member States.

Source: Egypt, Countries and regions, European Commission, accessed: 2 August 2021 
As for the remaining EU-27, Brussels apparently still considered Egypt a strategic partner for trade and security, last, but not least, to prevent migration and Islamic terrorism. According to Egypt's 2030 Vision, aimed at diversifying the country's economy, it became the secondlargest in Africa behind Nigeria in terms of nominal GDP (Economy of Egypt, Wikipedia). Egypt was the EU's 29th largest trading partner, representing $0.7 \%$ of the EU's total global trade in goods in 2020. At the same time, the EU was Egypt's biggest trading partner, covering $24.5 \%$ of Egypt's trade volume. Total trade in goods between the EU and Egypt amounted to $€ 24.5$ billion in 2020. Bilateral trade in services summed up to $€ 10.9$ bn in 2019 . The EU's main export of services to Egypt were business services, while the EU imported mainly travel services and transport from Egypt (Egypt, Countries and regions, European Commission, accessed: 2 August 2021).

\subsection{The socio-economic impact of the COVID-19 crisis on Egypt}

\section{Cartoon 4: Women's enlarged plight during Corona}

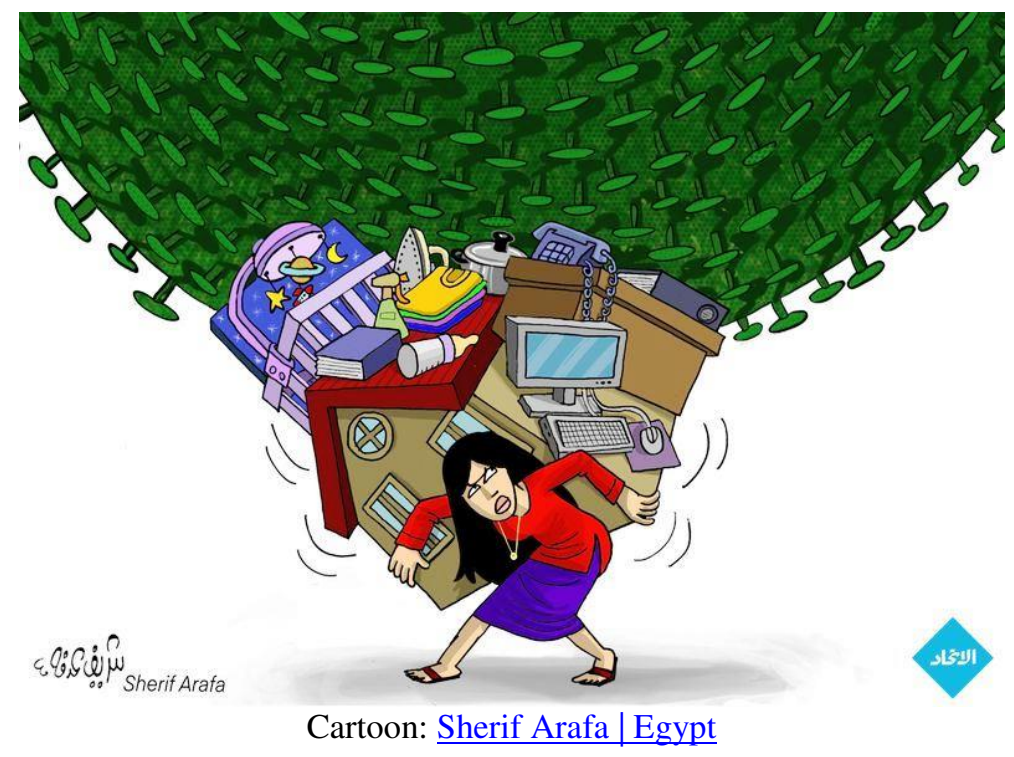

Africa's least developed countries (LDCs) are probably the most vulnerable concerning the impact of the COVI-19 pandemic, last, but not least, because of the general lack of vaccine. The first confirmed COVID-19 case was in Egypt on 14 February 2020 (Lone \& Ahmad, 2020). As of 2 August 2021 there were 284,000 confirmed cases and 16,528 death (Egypt: COVID-19; google.news, 2 August 2021)

The global economic impact of the COVID-19 pandemic on Egypt, including the indirect impact on income from the Suez Canal and remittances from Egyptians working abroad, was substantial. Both together accounted for about $14.5 \%$ of Egypt's GDP before the Corona crisis, and they were likely to decrease further. The poor and vulnerable were particularly affected. According to scholarly estimates at the beginning of the pandemic, household incomes would decline by between US\$ 9.70 (per person, per month; less pessimistic scenario) and US\$ 11.40 (more pessimistic scenario) for each month that the crisis persisted. The expected decline of tourism had the most severe impact, accounting for more than half of income loss. The predicted reduction of household income because of lower remittances affected notably poorer households in the rural areas with a decline of US\$ 6.60 to 8.20 , or between $11.5 \%$ and $14.4 \%$ (Breisinger, C. et al, 2020). 
Graph 14: number of COVID-19 cases and deaths in Egypt (logarithmic scale)

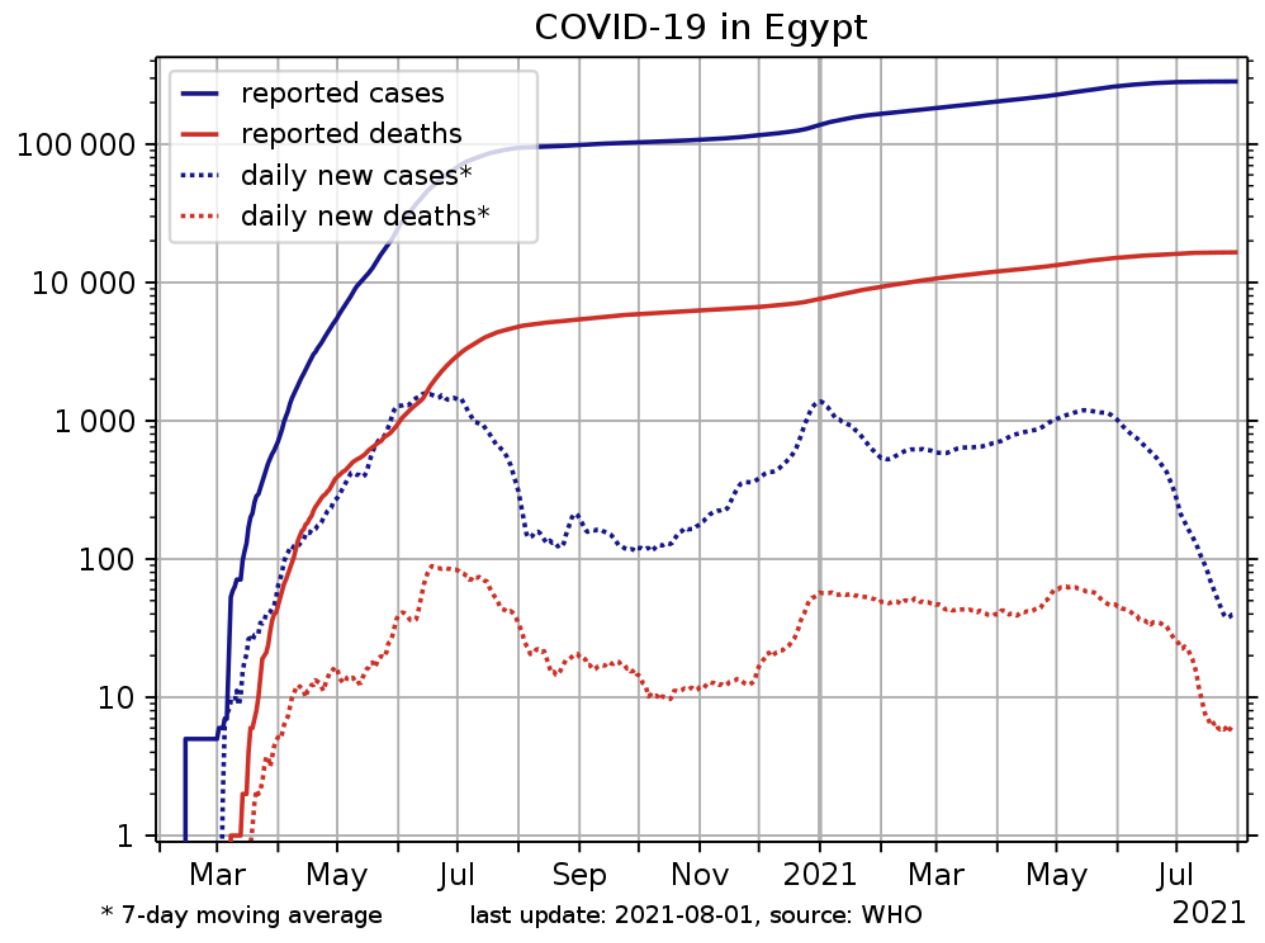

Source: COVID-19 pandemic in Egypt, Wikipedia

Graph 15: Confirmed COVID-cases in Egypt, March 2020 to July 2021

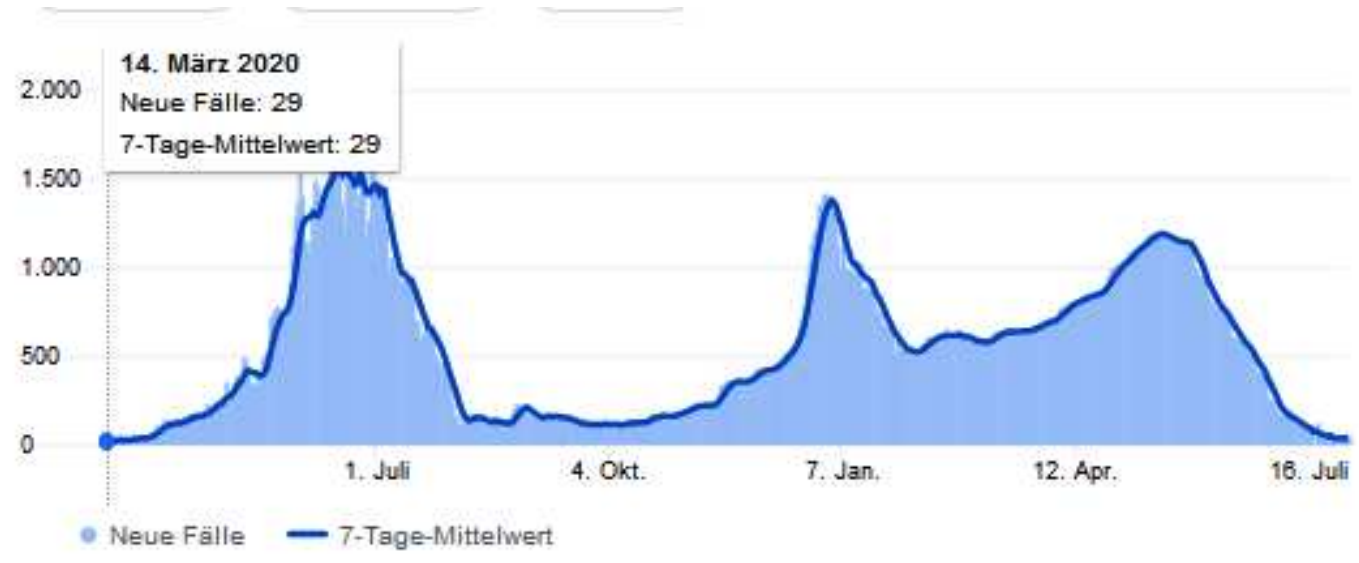

Egypt: COVID-19; google.news. Data source: Wikipedia und JHU CSSE COVID-19 Data

Furthermore, Cairo's response to the pandemic reduced the government's fiscal space significantly. Nevertheless, social interventions such as cash transfers, while providing some economic and social relief, could not impact poverty alleviation substantially (Elkhashen et al, 2020). Moreover, women were particularly affected across nearly every domain, from social protection to health, simply because of their gender. This applied even across social and economic classes, although the Egyptian government's response plan apparently reflected a new gender-sensitive strategy, e.g. in addressing issues like unpaid care work, and increasing also in cash benefits to female-headed households, and micro-financing to women entrepreneurs (Dokhan, 2021).

Again, there were observed severe psychological effects of the pandemic on the population. Women reported generally more severe depression, anxiety, and stress than men, a.o. because 
of a lack of emotional support from their family and society. Besides, expert analyses showed a more severe psychological impact among southern governorates (Beni-Suef and Assiut) than northern governorates (Cairo and Alexandria) (Arafa et al, 2020). Last, but not least, the Grand Sheikh of Al-Azhar, a prestigious Egyptian title in Sunni Islam, cautioned that the stigmatization and harassment associated with COVID-19 at work could have a substantial negative impact on physical and mental health (Abdelhafiz \& Alorabi, 2020).

\section{Conclusion}

Economists and economic literature agree that Brexit is likely to harm the UK's economy, including a significant decrease in the UK's real per capita income in the medium and long run. In contrast, proponents of the withdrawal of the UK from the EU, like Premier Boris

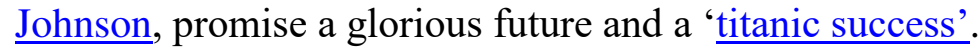

Whether Brexit will also impact 'Global Britain in a Competitive Age', including its former colonies, is open to question as well. London continued to follow its high flying ambitions, not just concerning the CANZUK union, meant to replace the lost EU-market access, but also vis à vis India and other big global players of the Commonwealth as well as the USA.

A particularly sensible case is the combined impact of Brexit and the COVID-19 pandemic on British foreign- and trade relations to Israel and its Arab neighbours. A destabilization of these countries could impact dangerously on the stability and security, not just of the MiddleEast region, but on the whole world. One of London's explicit post-Brexit foreign policy aims was to be more active in Africa (in particular East Africa and Nigeria), the Middle East and the Persian Gulf (Integrated Review, Wikipedia). So far, the preliminary effects in this respect are ambivalent. Whereas British voters entertained reasoned hope for a 'Corona miracle' and a marvellous economic recovery with a growth rate of about $7 \%$ in 2021, the prospects for Israel, the occupied Palestinian territories, Lebanon, Jordan and Egypt were less rosy.

According to preliminary data, Brexit will have only a limited impact on Israel's economic relations with the UK and the EU-27. But it is not to be excluded that Brexit could trigger a decline of Britain's traditional role as mediator between Europe and the US because Washington recognizes that London has had less influence in Brussels since the UK left the EU. This would have also repercussions for London that so far supported the US diplomacy, favouring Israel, which was biased against a truly independent Palestine state. The Corona pandemic affected particularly marginalized communities in Israel characterized by low socio-economic status and high residential density. However, a well-coordinated and centralized vaccination campaign made that the country had the highest vaccination rate in the world per capita. Thus, the death toll had been lower than in the hardest-hit OECD countries.

On the contrary, the Occupied Palestinian Territory was especially hard hit by the pandemic. Forecasts for the Palestinian economy for 2020 and 2021 were miserable. The West Bank for example recorded its lowest growth rate since 2012, while the Gaza strip's growth amounted to zero as it failed to recover from the two consecutive GDP contractions in 2017 and 2018 respectively. The unemployment rate increased from 31\% in 2018 to $33 \%$ in 2019 and the poverty rate from $25.8 \%$ to $29.2 \%$ between 2011 and 2017 . The volatile situation of the occupied territories was again aggravated by Jewish annexation. The COVID-19 pandemic still deepened the plight of the Palestinian people. Forecasts on the cost of the pandemic 
ranged between $7 \%$ to $35 \%$ of GDP, depending on assumptions about the severity and duration of the pandemic.

In Lebanon, the failure of the elite and the collapse of the state went hand in hand. The country was suffering from an economic crisis, which the World Bank counted among the ten, if not three, worst financial crises since the middle of the 19th century (Ehrhardt, 2021). The UK was only a minor economic player concerning Lebanese foreign trade and investment. The decrease of bilateral trade by $32.4 \%$ in 2020 (compared with 2019) was probably mostly due to the combined effects of the severe domestic political and economic crisis and the global economic effects of the Corona crisis, but less to Brexit. Deprivation did not strike just the Lebanese population, but particularly the large proportion of Syrian and Palestinian refugees in the country, equivalent to $21.7 \%$ and $6.7 \%$ of Lebanese total population respectively.

As for Israel's neighbour Jordan, the UK has been a central economic and security player. Amman remained reliant on the British capital concerning tourism and on aid. Britain will try to preserve its special relationship derived from colonial times, last, but not least, to maintain privileged access to Jordan's military and security markets. Yet, this British focus on security assistance was controversial. Most of Jordan's population would have preferred economic aid. Jordan's ongoing economic crisis resulted in mounting popular protests, now including the middle-class, with an increasing level of tension. The COVID-19 pandemic showed a dramatic surge since September 2020. Jordan became the Arab country with the highest number of COVID-19-related deaths per capita in October 2020. Given the life-threatening economic consequences, the poor and most vulnerable did not bother much about the observance of the strict anti-Corona measures.

Egypt and Britain have longstanding strong foreign relations in the political, defence, trade, and investment sectors. The two sides pledged to achieve greater free trade, notably in agricultural goods, which, however, would be difficult to justify vis à vis British farmers. Total bilateral trade in 2020 decreased by $18.1 \%$ from the year before. Probably most of the decrease was due to the global economic effects of the Corona crisis. In 2019, the outward stock of FDI from the UK in Egypt was not available due to data disclosure. However, the UK represented $41 \%$ of total FDI inflows into Egypt. This showed the importance of British investments to the Egyptian market, considering that the UK ranks fifth worldwide in outward FDI, and third in terms of inward FDI. Egypt's business was overwhelmingly in favour of Brexit. The global economic impact of the COVID-19 pandemic on Egypt, including the indirect impact on income from the Suez Canal and remittances from Egyptians working abroad, was substantial. The poor and vulnerable were particularly affected.

In short, Brexit is likely to harm the British in the medium and long run. The post-Brexit impact on Israel and its Arab neighbours will be negative too, but probably only be felt in the medium and long term as well. However, the direct and indirect negative effects of the global COVID-19 crisis will by far outdo the Brexit impact. 


\section{References}

Abdelhafiz, A.S. \& M Alorabi (2020): Social stigma: the hidden threat of COVID-19. Frontiers in public health, 2020 (8): 429, online 28 August 2020. doi: 10.3389/fpubh.2020.00429

Allam, Nancy (2016): What Does Brexit Mean for Egypt? Egyptian Streets, 24 June 2016 -

Al-Tammemi, Ala'a B. \& Zeinab Tarhini, Amal Akour (2021): A swaying between successive pandemic waves and pandemic fatigue: Where does Jordan stand? Annals of Medicine and Surgery, vol. 65, May 2021

Arafa, A. \& A. Mohamed \& L. Saleh \& S. Senosy (2020): Psychological impacts of the COVID-19 pandemic on the public in Egypt. Community mental health Journal vol. 57, pp. 64-69

Birenbaum-Carmeli, D., Chassida, J. (2021): Health and socio-demographic implications of the Covid-19 second pandemic wave in Israel, compared with the first wave. Int J Equity Health 20 , 154 (2021). https://doi.org/10.1186/s12939-021-01445-y

Breisinger, C. et al (2020): Economic impact of COVID-19 on tourism and remittances: Insights from Egypt. Washington D.C.: International Food Policy Reserch Institute (IFPRI), DOI : https://doi.org/10.2499/p15738coll2.133762_12

Chaban, Natalia \& Arne Niemann \& Johanna Speyer (eds.)(2020): Changing Perceptions of the EU at Times of Brexit: Global Perspectives. London: Routledge

Cottrell, James H. Jr (2020): The Tripartite Relationship between Britain, Israel and United States: Effects of Brexit on the Israeli State. Lexology.com, Holland \& Knight LLP, September 102020

DIT (2021): UK trade agreements with non-EU countries. Department for International Trade, London

Dokhan, N. A. (2021): The Impact of Global Crises on Women: The Case of Covid-19 in Egypt - The American University in Cairo, thesis

Elkhashen, E.M. \& A Sarhan \& A. Ejiogu (2020): Egyptian budgetary responses to COVID-19 and their social and economic consequences. Washington D.C.: International Food Policy Research Institute (IFPRI), JPBAFM, vol. 33 (1), 29 September 2020

El-Shimy, N. (2017): The Impact of British Exit (Brexit) From the European Union On EgyptianBritish Relations. platform.almanhal.com

Ehrhardt, Christop (2021): Das Trauma kann nicht heilen. Frankfurter Allgemeine Zeitung (faz+),. 4 August 2021

EU (2021): EU disburses $€ 250$ million in Macro-Financial Assistance to Jordan. The European Sting, Brussels, n.A., July 21, 2021

Fereira, Francisco H. G. (2021): Inequality in the Time of COVID-19. Finance \& Development, IMF, June 2021: 20-23

Giles, Chris (2021): Covid pandemic masks Brexit impact on UK economy. London: Financial Times (FT), July 1, 2021

Greene, Toby (2019): The real danger that Brexit poses for Israel. Queen Mary University of London / UK in a changing Europe, 29 October 2019

Halawi, Dana (2016): Lebanon expects Brexit benefits in EU import bills. Albawaba, June 27th, 2016

Hajjar, Marwan S. \& Ghassan S Abu-Sittah (2021): The multidimensional burden of COVID-19 on Syrian refugees in Lebanon. J Glob Health., vol. 11, published online, 16 January 2021; doi: 10.7189/jogh.11.05003

Kebede, T.A. \& S.E. Stave \& M. Kattaa \& M. Prokop (2020): Impact of the COVID-19 pandemic on enterprises in Jordan. Geneva: Int. Labour Organization (ILO) /UNDP, 2020 
Khatatbeh, Moawiah et al (2021) Psychological Impact of COVID-19 Pandemic Among the General Population in Jordan. Frontiers in Psychiatry. Published online 14 April 2021. doi: 10.3389/fpsyt.2021.618993

Kohnert, Dirk (2021): Brexit and CANZUK : expectations versus realities. BLOG, UK-in-aChanging-Europe, 8.July 2021

Kohnert, Dirk (2021 a) : A 'titanic success'? Away from the EU, back to the UK's old Commonwealth allies: Boris Johnson dreams of an alternative to the EU with a new free trade agreement. ips-journal, 23. July 2021

Lone, S. A. \& A. Ahmad (2020): COVID-19 pandemic-an African perspective. Emerging microbes \& infections, vol. 9 (1) doi.org/10.1080/22221751.2020.1775132

Mehling, Nicholas (2016): Brexit for Egypt: the good, the bad, and the uncertain. While global economic attention is turned to the effects of the UK's departure from the EU, Egypt stands to gain. Daily News - Egypt,_June 27, 2016

Miaari, Sami H. \& Maha Sabbah-Karkabi \&Amit Loewenthal (2020): How Is the COVID-19 Crisis Exacerbating Socioeconomic Inequality among Palestinians in Israel? Bonn: Institute of Labour Economics, IZA DP No. 13716, September 2020

Miskimmon, A. \& B. O'Loughlin (2019): Narratives of the EU in Israel/Palestine: narrative "stickiness" and the formation of expectations. European security, vol 28 (3), pp. 268-283

Moawad, Paul \& Lauren Andres (2020): Tackling COVID-19 in informal tented settlements (Lebanon): An assessment of preparedness and response plans and their impact on the health vulnerabilities of Syrian refugees. Journal of Migration and Health, vol. 1-2, 2020, 100011

MoD ( 2019): Jordan CSSF: Defence and Borders. London: Ministry of Defence (MoD), Foreign and Commonwealth Office (FCO)

Moslem, Ali (2019): Will Brexit affect Egypt-UK economic relations? ahram.online, 30 September 2019

N.A. (2020): UK, Egypt sign post-Brexit trade agreement. Arab-news, No author given, 5 December 2020

Navon, Emmanuel (2019): Israel's European Dilemma. Israel Journal of Foreign Affairs, 2018, vol. 12 (3), pp 325-331 | Published online: 20 Mar 2019

OECD (2021): OECD Economic Surveys: Israel 2020 - Key Policy Insights. Paris: Organisation for Economic Co-operation and Development (OECD)

Plickert,Philip (2021). Briten staunen über mögliches ,Corona-Wunder'. Frankfurter Allgemeine Zeitung (faz), 4 August 2021. English translation by Hall, Susan (2021): Corona in Great Britain: British are amazed at "Corona miracle". Fuzzy Skunk, 4 august 2021

Quilliam, Neil (2021): UK must stop talking and take action on Israeli-Palestinian conflict. Chathamhouse.org, 26 May 2021

Robertson, Nic (2019): Theresa May failed to turn on the charm in Sharm. CNN, 25 February 2019

Rossman, H., Shilo, S., Meir, T. et al. (2021): COVID-19 dynamics after a national immunization program in Israel. Nat Med , 27, 1055-1061 . https://doi.org/10.1038/s41591-021-01337-2

Sayers, Beatrice (2019): Celebrating mockery that has no mercy. London: Jewish News (i.e. a British Jewish Community website of anglo-Jewry's most read newspaper, according to its own rating), November 25, 2019

Samuel-Azran, T. \& Galily, Yair (2018) Israeli Media and the EU Referendum 2016: Political or Economic Story? In : Ridge-Newman A., León-Solís F., O'Donnell H. (eds): Reporting the Road to Brexit. Palgrave Macmillan, Cham., pp 295-304. https://doi.org/10.1007/978-3-319-73682-2 17 
Siman-Tov, D. \& R Schulman (2020): Report on British intelligence in face of Russian influence : The significance for Israel. London: Institute for National Security Studies, INSS Insight, No. 1361, August 12, 2020

Strenger, Carlo (2018): Brexit reflects EU's failure to create a European identity - and Israel should take Heed. Haaretz, June, 2016 (online English edition of Haaretz Newspaper in Israel, updated: April 10, 2018)

Salameh, Pascale et al (2020): Mental Health Outcomes of the COVID-19 Pandemic and a Collapsing Economy: Perspectives from a Developing Country (Lebanon). Psychiatry Research, vol. 94, December 2020, 113520

UNCTAD (2020): COVID-19 devastates Palestine's shattered economy. Geneva: United Nations Conference on Trade and Development (UNCTAD), 8 September 2020

UNHCR (2021): Lebanon. Year-end report, 2020. Geneva: United Nations High Commissioner for Refugees (UNHCR)

Walsh, Alex (2019): A Way Forward for U.K.-Jordan Security Cooperation. Carnegie-Endowment, 8 November 2019

Yeung, Peter (2020): How might Brexit impact the Middle East? Aljazeera, 30 Dec 2020

Résumé : Les effets combinés du Brexit et de la pandémie de COVID-19 sur les relations étrangères et commerciales britanniques avec Israël et ses voisins arabes constituent un cas particulièrement sensible. Une déstabilisation de ces pays pourrait avoir un impact sérieux sur la stabilité et la sécurité, non seulement de la région du Moyen-Orient, mais dans le monde entier. Jusqu'à présent, les effets préliminaires sont ambivalents. Alors que les Britanniques nourrissaient un espoir raisonné d'un « miracle de Corona » et d'une merveilleuse reprise économique en 2021, les perspectives pour Israël, les territoires palestiniens occupés, le Liban, la Jordanie et l'Égypte étaient moins roses. Vraisemblablement, le Brexit est susceptible de nuire au Royaume-Uni à moyen et long terme. L'impact post-Brexit sur Israël et ses voisins arabes sera également négatif, mais ne se fera probablement sentir qu'à moyen et long terme aussi. Cependant, les effets négatifs directs et indirects de la crise mondiale du COVID-19 dépasseront de loin l'impact du Brexit.

Zusammenfassung: Die gemeinsamen Auswirkungen des Brexits und der COVID-19Pandemie auf die britischen Außen- und Handelsbeziehungen zu Israel und seinen arabischen Nachbarn sind ein besonders heikler Fall. Eine Destabilisierung dieser Länder könnte die Stabilität und Sicherheit nicht nur im Nahen Osten, sondern auf der ganzen Welt ernsthaft gefährden. Bisher erscheinen die vorläufigen Effekte ambivalent. Während die Briten begründete Hoffnungen auf ein „Corona-Wunder“ und eine erstaunliche wirtschaftliche Erholung im Jahr 2021 hegen, sind die Aussichten für Israel, die besetzten palästinensischen Gebiete, den Libanon, Jordanien und Ägypten weniger rosig. Vermutlich wird der Brexit dem Vereinigten Königreich mittel- und langfristig schaden. Die post-Brexit Auswirkungen auf Israel und seine arabischen Nachbarn werden ebenfalls negativ s, aber vermutlich ebenfalls nur mittel- und langfristig zu spüren sein. Die direkten und indirekten negativen Effekte der weltweiten COVID-19-Krise werden jedoch die Folgen des Brexits bei weitem übertreffen. 